\title{
"IN DANGER OF BECOMING MORALLY DEPRAVED": SINGLE BLACK WOMEN, WORKING-CLASS BLACK FAMILIES, AND NEW YORK STATE'S WAYWARD MINOR LAWS, 1917-1928
}

\author{
CHERYL D. Hicks ${ }^{\dagger}$
}

\section{INTRODUCTION}

In 1923, Gail Lewis attended a local Fourth of July party.' Instead of coming directly home after realizing that she had broken her curfew, the black seventeen-year-old New York native decided to stay out all night and face her parents, especially her father whom she feared would be angered by her actions, the following day. ' Clearly, Lewis's broken curfew and night away from home violated her parents' rules, but her actions also indicated, in her parents' estimation, her potential for future inappropriate behavior. When she finally returned home, her parents had already notified the police. ${ }^{3}$ Although school officials reported her skirmishes with fellow classmates, Lewis was considered well behaved and not a juvenile delinquent. ${ }^{4}$ In fact, when notified about her arrest, Lewis's pastor replied in disbelief: "I was never more surprised ... . I am certain that there must have been some evil influence in her straying away." Lewis's parents' fear of that "evil in-

\footnotetext{
${ }^{\dagger}$ Assistant Professor, Department of History, Williams College. For their helpful comments, criticisms, and encouragement, I would like to thank Elsa Barkley Brown, Kali N. Gross, Tera Hunter, Kenda Mutongi, Nell Irvin Painter, Nichole T. Rustin, Robyn C. Spencer, Kimberly Springer, and Craig S. Wilder. I would also like to thank the panel participants and audiences at the 12th Berkshire Conference on the History of Women and at the conference on Law and the Disappearance of Class in the Twentieth-Century United States. I want to specifically express my appreciation for the editorial assistance and patience of Lena Amanti.

'History Blank (July 10, 1923) (on file with N.Y. State Archives and Records Administration, State Education Department, Albany, N.Y., Bedford Hills Correctional Facility, Inmate Case Files circa 1915-1930, 1955-1965 (Bedford Hills Files), Inmate No. 3476) [hereinafter History Blank, Inmate No. 3476]. In this Article, I have used pseudonyms for inmates' names but have retained original inmate case numbers.

Id.

${ }^{3} I d$.

${ }^{4} I d$.

${ }^{5}$ Letter from George H. Sims, Reverend, Union Baptist Church, to Amos T. Baker, Superintendent, New York State Reformatory for Women at Bedford 1 (Oct. 2, 1923) (on file with Bedford Hills Files, Inmate No. 3476).
} 
fluence" directed their response to their daughter's behavior, as they "entered a complaint" against her for violation of New York State's wayward minor law." This statute criminalized female disobedience and sexual delinquency as a proactive means of protecting young women from urban vice. Lewis was arrested and imprisoned in the New York State Reformatory for Women at Bedford (Bedford) for being "wilfully disobedient," but more importantly from her parents' perspective, for being "in danger of becoming morally depraved."

The Lewis case reveals a relatively unexplored issue within the scholarship on early-twentieth-century urban-reform campaignsnamely, black working-class families' anxieties about single black women's moral behavior and proactive attempts to protect them. Expanding our understanding and conception of social welfare reform and black urban life, this Article examines how some black working-class families-who were not prominent in social welfare reform and who were not considered black elites-actively participated in the efforts to protect and, ultimately, to control young black women. Shifting the historical discussion of black women's protection, which has usually centered on the efforts of black and white reformers, ${ }^{10}$ this Article also shows how black working-class families attempted to protect the reputations of their young women and to monitor their lifestyles. In this sense, the single black woman was not just the lone southern migrant or independent urban

${ }^{6}$ History Blank, Inmate No. 3476, supra note 1.

7 Act of May 29, 1923, ch. 868, 1923 N.Y. Laws 1687.

${ }^{8}$ See id. $\$ 1,1923$ N.Y. Laws at 1687 (penalizing women between the ages of sixteen and twenty-one who were "habitually addicted to the use of drugs" or alcohol, who "habitually associate[d] with dissolute persons," who were found in a "house of prostitution or assignation or ill fame," or who "habitually associate[d] with thieves, prostitutes, pimps or procurers or disorderly persons").

${ }^{9}$ E.g., Act of Apr. 21, 1920, ch. 295, $\$ 1,1920$ N.Y. Laws 848, 848; see also infra note 24 and accompanying text (discussing the law's use of the "in danger of becoming morally depraved" language).

${ }^{10}$ For literature surveying the attempts made by reformers to safeguard young black women, see EVEIIN BRoOKS Higginbotham, RightEOUS DisconTENT: THE WOMEN'S MOVEMENT IN THE BLACK BAPTIST CHURCH 1880-1920, at 180-84 (1993); Guichard Parris \& LeSTER BROOKS, Blacks IN THE CIIY: A History OF THE National Urban league 3-10 (1971); Dorothy C. Salem, To Better OUR World: BLACK WOMEN IN ORGANIZED REFORM, 1890-1920, at 44-48 (1990); JUDITH WEISENFELD, AFRICAN AMERICAN WOMEN AND CHRISTIAN ACTIVISM: NEW YORK'S BLACK YWCA, 1905-1945, at 133-43 (1997); NANCY J. WEISS, THE NATIONAL URBAN LEAGUE: 1910-1940, at 15-20 (1974); Linda Gordon, Black and White Visions of Welfare: Women's Welfare Activism, 1890-1945, 78 J. AM. HIST. 559, 578-80 (1991); Christina Simmons, African Americans and Sexual Victorianism in the Social Hygiene Movement, 1910-40, 4 J. Hist. Sexuality 51, 62-63 (1993). 
dweller-who, reformers argued, needed moral guidance and domestic training in order to adjust to, and survive in, cities-but also the young black woman living with her family in the city. This Article, as a result, highlights family members' concerns regarding morality as well as their proactive attempts to maintain a semblance of stability within their communities." Moreover, this Article argues that the complexity of the black working-class experience included a sense of entitlement to state services as well as the unexpected, and in many cases negative, consequences of aligning with the State.

Gail Lewis's parents' use of New York's wayward minor laws clearly demonstrates how some black working-class families consciously turned to the courts to regulate what they defined as the transgressive behavior of their female relatives. Indeed, the clashes between young women and their relatives over what they viewed as appropriate behavior caused tremendous conflict within black families. The legal, and ultimately unequal, relationship between young black women, their parents and kin, and the State dramatically affected black families' expectations from and experiences with the State." Examining the

${ }^{11}$ Generally, the assessments of scholars and public policymakers have placed black women at the center of problems within black families and communities. E.g., E. Franklin Frazier, THE NEgro Family in the United States (1939); Herbert G. GutMAN, THE BlaCK FAMILY IN SLAVERY AND FREEDOM, 1750-1925 (1976). Herbert Gutman's work was written in response to the controversial 1965 report by Senator Daniel Patrick Moynihan, in which Senator Moynihan argued that the disorganization, increased crime, and pathology in the black community in general, and black men's problems in particular, were the result of the black family's matriarchal structure. See $i d$. at xvii ("This volume ... was stimulated by the bitter public and academic controversy surrounding [Daniel Patrick Moynihan, The Negro Family: The Case for National Action, in THE MOYNIHAN REPORT AND THE POLITICS OF CONTROVERSY 39 (Lee Rainwater \& William L. Yancey eds., 1967)]."); see also DONNA L. FRANKLIN, ENSURING INEQUALITY: THE STRUCTURAL TRANSFORMATION OF THE AFRICAN-AMERICAN FAMILY 166 (1997) ("The most serious fallacy in the report was that Moynihan apparently presumed that black mothers were increasingly single by choice, which led him to look for ways to break up a "matriarchal culture."); Brenda E. Stevenson, Black Family Stmucture in Colonial and Antebellum Virginia: Amending the Revisionist Perspective, in THE DECLINE

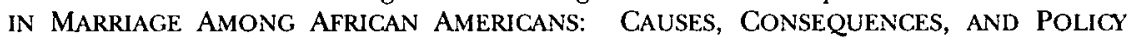
IMPLICATIONS 27, 32-34 (M. Belinda Tucker \& Claudia Mitchell-Kernan eds., 1995) (discussing Gutman's response to Moynihan's report). While this Article addresses the ways in which young black women's behavior affected their families and the ways that family members addressed those problems, it also illustrates that these young women were not the cause of their community's downfall and that their behavior, like that of young wayward white women, was not a reflection upon their families' or race's values.

${ }^{12}$ Mary Odem's work on working-class parents and their daughters in Alameda and Los Angeles Counties in California provides a significant exploration of these issues. MARY ODEM, DELINQUENT DAUghters: Protecting AND Policing ADOLESCENT FEMAle SEXUAlity IN THE UNITEd STATES, 1885-1920 (1995). She argues, "Rather than seeing the court system as a top-down model of class control,... we 
ways in which black communities interpreted the law and used the State to regulate single women raises new questions about black women, their families, and urban reform. When their individual efforts to discipline young women failed, why did some families turn to the State for support? How did New York State reformers and administrators respond to the needs and requests of working-class black families? And finally, in light of the prejudices that reformers held when dealing with working-class persons generally, ${ }^{13}$ how did the racebased choices reformers made affect black relatives' abilities to use the law successfully to protect and to monitor their young women? In addressing these issues, I examine the fifteen existing case files of black women sentenced to Bedford between 1917 and 1928. ${ }^{14}$ While not purporting to present a representative sample of black working-class families in New York during this period, this Article's use of Bedford's case files reveals a need to challenge many of the general claims made about working-class black families, specifically concerning their structure, concerns, and ability to assert their own moral voice. ${ }^{15}$

should conceive of it as a triangulated network of struggles and negotiations among working-class parents, their teenage daughters, and court officials." Id. at 158; see also Ruth M. Alexander, The "Girl Problem": Female Sexual Delinguency in New YORK, 1900-1930, at 103 (1995) ("Although we might think of the dynamic of reform as one that exclusively involved the inmates and their keepers, it was actually a threeway affair, bringing young women, reformatory officials, and family members together to wrestle over goals and methods.").

${ }^{13}$ See sources cited supra note 10 (examining the racial stereotypes inherent in many reformers' visions for black families).

${ }^{4}$ For these years, records exist for seventy-three wayward minor cases. The following inmates constitute the fifteen wayward minor cases involving black women: Inmate Numbers 2486, 2503, 2682, 3365, 3367, 3374, 3387, 3476, 3708, 3711, 4028, $4035,4059,4107$, and 4498.

${ }^{15}$ My examination of working-class families' relationships with young women and the State addresses issues such as generational conflict, young women's independence, and gendered interpretations and responses to State assistance. While many studies of this issue emphasize the class component, this Article addresses the specific perspectives of black working-class families and female offenders. For the discussions of social control, gender, and class in relation to young women and familial conflict that influenced my understanding of young, incorrigible black women, see ALEXANDER, supra note 12; Barbara M. Brenzel, Daughters of the State: A Social Portrait Of THE FIRST REFORM SCHOOL FOR GIRLS IN NORTH AMERICA, 1856-1905 (1983); LINDA Gordōn, heroes of THEIR OWN lives: THE Politics and History of Family VIOLENCE, BOSTON 1880-1960 (1988); ODEM, supra note 12; CHRISTINE STANSELL, CITY OF WOMEN: SEX AND ClaSS IN NEW YORK, 1789-1860 (Illini Books ed., Univ. of III. Press 1987) (1982); CARolyn Strange, Toronto's Girl Problem: The Perils and Pleasures OF THE CiTY, 1880-1930 (1995); Elizabeth Lunbeck, "A New Generation of Women": Progressive Psychiatrists and the Hypersexual Female, 13 Feminist STUd. 513 (1987); Joan Sangster, Incarcerating "Bad Girls": The Regulation of Sexuality Through the Female Refuges Act in Ontario, 1920-1945, 7 J. Hist. SexuAlity 239 (1996); Joan Sang- 
This Article addresses how black working-class families sought to protect and police their female relatives by using New York State's wayward minor laws between 1917 and 1928. Examining urban reform through the actions of black working-class parents and relatives illuminates how black communities interpreted the law and used the State to regulate their female kin's behavior. This focus shifts the historical discussion of black women's protection away from the efforts of elite black and white reformers and addresses the concerns of black working-class families. In doing so, this Article argues that the complexity of the black working-class experience included a sense of entitlement to state services as well as the unexpected, and in many cases, negative consequences of aligning oneself with the State. Black families' active involvement in the reform process, through the use of the wayward minor laws, illustrates how these families enacted their grave concerns and anxieties about the reputations and lifestyles of their female kin through the State. This level of involvement also challenges general assertions about working-class black communities' capacity for, and ability to, enact moral stature. Nevertheless, racism within the criminal justice system-segregated rehabilitative institutions and limited probation servies-underlied the basic attempts of those relatives who used the wayward minor laws to regulate their female kin's behavior and stabilize family relationships. While there were some instances where the State addressed parental concerns successfully, unequal power dynamics between the State and the working class usually resulted in parents and guardians losing their natural and legal authority over their female kin.

\section{THE WAYWARD MINOR LAWS AND THEIR RELEVANCE FOR BLACK FAMILIES}

The New York State wayward minor laws ${ }^{16}$ provided a means by which working-class families could address the questionable behavior

\footnotetext{
ster, She Is Hostile to Our Ways: First Nations Girls Sentenced to the Ontario Training School for Girls, 1933-1960, 20 LAW \& HIST. REV. 59 (2002).

${ }^{16}$ I use the term "wayward minor laws" to refer to all of the iterations of the law that governed the conduct of young delinquent women, although the law was not referred to as such until 1923. See Act of May 29, 1923, ch. 868, § 1, 1923 N.Y. Laws 1687 , 1687 (defining conduct for which a young female could be deemed a "wayward minor").
} 
of their female kin. This Article focuses on the laws' interactions with black families. ${ }^{17}$

\section{A. The Historical Development of the Wayward Minor Laws}

New York's wayward minor laws date back to an 1882 New York City municipal law ${ }^{18}$ that was "designed to control those girls from fourteen to twenty-one who, charged with being prostitutes, had professed a desire to reform," by committing them to reformatory institutions. $^{19}$ In 1886, the New York State legislature amended the law to include incorrigible female behavior more generally. ${ }^{20}$ At this time the law became known as the "incorrigible girl statute." ${ }^{21}$ The 1886 law enabled parents and legal guardians (as well as the police) to commit young women whom they believed were delinquent through their testimony in court. ${ }^{22}$ The statute criminalized incorrigible behavior and noted that those young women indicted under the law should be committed to a private reformatory institution. ${ }^{23}$ Magistrates could sentence young women who were at least twelve years old upon a finding that these women were found in a "reputed" house of prostitution, were "frequenting the company of thieves or prostitutes," were found "associating with vicious and dissolute persons," or were "willfully disobedient to parent or guardian, and [thus] in danger of becoming morally depraved."

${ }^{17}$ For a similar discussion concerning working-class white women, both foreign and native born, see ALEXANDER, supra note 12; BRENZEL, supra note 15; ODEM, supra note 12 .

${ }^{18}$ New York City Consolidation Act of 1882, ch. 410, 1882 N.Y. Laws 367.

${ }^{19}$ Paul W. TAPPAN, Delinguent Girls in COURT: A STUdY OF THE WAYWARD MiNOR COURT OF NEW YORK 44 (Patterson Smith Reprint Series in Criminology, Law Enforcement, \& Soc. Problems, Publ'n No. 67, 1969).

${ }^{20}$ See Act of May 13, 1886, ch. 353, $\$ 1,1886$ N.Y. Laws 559, 560 (expanding the covered conduct to other forms of delinquency in addition to prostitution, and applying the law to any woman over the age of twelve).

${ }^{21}$ ALEXANDER, supra note 12, at 50.

22 The 1886 law provided:

Whenever any female ... shall be brought by the police, or shall voluntarily come before a committing magistrate... and it shall be proved... by the confession of such female, or by competent testimony, that such female [engaged in delinquent behavior,] ... such magistrate may judge that it is for the welfare of such female that she be placed in a reformatory ....

Act of May 13, 1886, § 1, 1886 N.Y. Laws at 560.

${ }^{29}$ See id. (listing the private institutions to which a young woman could be committed).

${ }^{24}$ Id. The law retained this language until the 1923 amendments. Compare Act of May 7, 1903, ch. 436, $\$ 1,1903$ N.Y. Laws 1022, 1022 (utilizing the "in danger of be- 
Legislators consistently modified the statute, ${ }^{25}$ and in 1923 the legislature amended the statute for "the commitment, custody and control of wayward minors." At this time, the law became known as the "wayward minor statute." ${ }^{27}$ Under the 1923 statute, young women between the ages of sixteen and twenty-one could be committed under the same conditions as the earlier incorrigibility statutes, with the addition that those women found to be "habitually addicted to the use of drugs or the intemperate use of intoxicating liquors" could also be indicted. $^{28}$ When young men were first covered by the statute in $1925,{ }^{29}$ court officers and administrators reinforced the idea that, like young women who had been subject to the law since 1882, they were not seen as having "committed [a] serious offense against the law, but they were certainly [thought to be] entering on the road which would eventually find them in its clutches."

While defining the parameters of inappropriate female behavior, the laws specifically encouraged parental and community monitoring of young women's behavior by providing a means to discipline morally wayward and rebellious girls through the courts. The laws from 1882 to 1920 provided that local private reformatories, like the Protestant Episcopal House of Mercy, the Roman Catholic House of Good Shepherd, the New York Magdalen Benevolent Society, and the Jewish Protectory and Aid Society, could serve as the sites for young women's moral rehabilitation. ${ }^{31}$ Although Bedford opened in 1901, and re-

coming morally depraved" phrase), Act of Apr. 20, 1914, ch. 445, \$ 1, 1914 N.Y. Laws 1905,1906 (same), and Act of Apr. 21, 1920, ch. 295, $\$ 1,1920$ N.Y. Laws 848, 848 (same), with Act of May 29, 1923, ch. 868, § 1, 1923 N.Y. Laws 1687, 1687 (adding addiction to drugs or alcohol as behavior for which one could be adjudged a wayward minor, and eliminating the "in danger of becoming morally depraved" language). See generally ALEXANDER, supra note 12, at 50-51 (describing the passage of these laws).

${ }^{25}$ See Act of May 7, 1903, \$ 1, 1903 N.Y. Laws at 1022 (adding petit larceny as a basis for committal); Act of Apr. 20, 1914, $\$ 1,1914$ N.Y. Laws at 1906 (modifying the list of institutions available for commitment); Act of Apr. 21, 1920, § 1, 1920 N.Y. Laws at 849-50 (providing for parole and for the return to court of women deemed unfit for rehabilitation).

${ }^{26}$ Act of May 29, 1923, pmbl., 1923 N.Y. Laws at 1687.

27 See, e.g., AlEXANDER, supra note 12, at 51 ("In 1923 New York passed the Wayward Minor Act ....").

${ }^{28}$ Act of May 29, 1923, $\$ 1,1923$ N.Y. Laws at 1687; see also ALEXANDER, supra note 12, at 51-52 (charting the expansions made in the 1923 law).

${ }^{29}$ See Act of Apr. 8, 1925, ch. 389 , secs. 1-2, $\$ \$ 913-$ a to -d, 1925 N.Y. Laws $711,711-$ 12 (substituting the word "person" for "female").

${ }^{30}$ Patrick J. Shelly, Wayward Minors Put Under New Law's Guidance, N.Y. TIMES, May 7, 1926, at X19.

${ }^{31}$ E.g., Act of Apr. 20, 1914, ch. 445, $\$ 1,1914$ N.Y. Laws 1905, 1906. In the 1923 amendments, the legislature eliminated the names of specific private reformatories 
ceived young incorrigible women at that time,${ }^{32}$ it was not until 1920 that the state legislature revised the incorrigibility statute to allow courts to send young women to Bedford. ${ }^{33}$ Young women who caused continuous disciplinary problems, or were deemed "unfit[] to benefit [from] the discipline and training" that the reformatories offered, were returned to court and then sent to Bedford for up to three years. $^{34}$ This change marked the Bedford commitment as the final, and most serious, stage in the institutional reform of young women charged with wayward behavior.

\section{B. Viewing Black Families Through the Lens of the Wayward Minor Laws}

State legislators and reformers used the incorrigibility and wayward minor laws to regulate what they saw as improper parenting within working-class, native-born and immigrant, white and black families. ${ }^{35}$ When family members brought their female kin to court for repeated disobedience, it underscored the legislators' assumption that the working class was not capable of parenting. Reformers' and administrators' definitions of incompetence ranged from the inability of immigrants to assimilate American customs to the inability to control their female kin. For instance, one administrator noted that a woman deserved to be institutionalized because her parents, "although good people ... with a good home, were not able to control"

and provided for commitment in "any religious, charitable or other reformative institution authorized by law to receive commitments." Act of May 29, 1923, § 1, 1923 N.Y. Laws at 1687 .

${ }^{32}$ See AlEXANDER, supra note 12, at 50 ("After it opened in 1901, the state reformatory at Bedford Hills . . . accepted 'incorrigible' and 'ungovernable' young women.").

Act of Apr. 21, 1920, ch. 295, \$5, 1920 N.Y. Laws 848, 850.

34 Id:; see also ALEXANDER, supra note 12, at 49-54 (citing examples of young women being sent to Bedford and describing the reasons for their sentences).

${ }^{35}$ See AlEXANDER, supra note 12, at 52 ("While New York's incorrigible-girl and wayward-minor laws upheld the principle of filial obedience, they simultaneously affirmed the state's obligation to compensate for the ineptitude of working-class, immigrant, and African American parents by devising measures to restore young women to lives of morality and obedience."); ODEM, supra note 12, at 150 ("The juvenile court functioned as a place of moral instruction and discipline of working-class parents as well as their daughters. Parents were required to attend court hearings with their daughters, and there they frequently found themselves subject to the scrutiny of court officials."); Shelly, supra note 30 (blaming parents for the delinquency of their children). 
their daughter. ${ }^{36}$ Other reformers and administrators shared a belief, articulated by probation officer Patrick J. Shelly of the New York City Magistrates' Courts, that "[a]t the root of all delinquency [was] improper home environment, which include[d] a lack of religious teaching of any kind, and bad example or downright indifference on the part of parents." ${ }^{37}$ Thus, state representatives concluded that their parents' and guardians' incompetence contributed to their downfall.

When dealing with black families, reformers questioned the moral stature of these working-class communities. ${ }^{38}$ Black and white reformers, working from an assumption of black working-class immorality, sought to isolate those individuals they believed were in need of guidance and uplift from their social and racial superiors. ${ }^{39}$ Black reformers believed that they needed to uplift the working-class masses by participating in social welfare reform efforts and by guiding the masses through their example. ${ }^{40}$ Victoria Earle Matthews, a prominent black clubwoman, consistently stressed the need for racial uplift. ${ }^{41}$ Mat-

${ }^{36}$ Author's Notes, Letter from Helen Cobb, Superintendent, Bedford, to J.A. Armstrong, Justice of the Peace (Aug. 17, 1917) (original on file with Bedford Hills Files, Inmate No. 2503).

${ }^{37}$ Shelly, supra note 30.

${ }^{38}$ See, e.g., FRAZIER, supra note 11, at 483 ("[T] he maternal-family organization [of black working-class communities] has also been tied up with widespread illegitimacy.... Although formal education has done something in the way of dispelling ignorance and superstition, it has effected little change in the mores and customs of these folk communities."); Frances A. Kellor, The Criminal Negro: Some of His Characteristics, 25 THE ARENA 308, 310 (1901) (discussing drinking, gambling, and fighting, and then concluding that the "social life of the negro lacks direction, restraint, and healthy interests"); Frances A. Kellor, The Criminal Negro: Southern Conditions that Influence Negro Criminality, 25 THE ARENA 190, 190 (1901) (arguing that the "moral instincts" of blacks "often remain undeveloped").

39 See KEVIn K. Gaines, Uplifting the RaCE: BLaCk Leadership, POlitics, AND CULTURE IN THE TWENTIETH CENTURY 158-59 (1996) ("As illicit pleasures and pastimes [such as visiting saloons and dance halls, along with prostitution and gambling] were increasingly confined to black neighborhoods, urban immorality was. frequently imbued with a racial stigma. Moral reformers focused their efforts on black sections as those most contagious portions of the social organism.").

${ }^{40}$ See id at 152-78 (discussing racial uplift ideology and W.E.B. DuBois). For a cogent analysis of the response of white liberal reformers (such as Louise de Koven Bowen, Frances Kellor, and John Daniels), see ELISABETH LASCH-QUINN, BLACK NEIGHBORS: RACE AND THE Limits OF REFORM IN THE AMERICAN SETTLEMENT HOUSE MOVEMENT, 1890-1945, at 11-23 (1993).

${ }^{41}$ FLORIS BARNeTt CASH, AFrICAN AMERICAN WOMEN AND SOCIAL ACTION: THE Clubwomen and Volunteerism from Jim Crow to THE New DEAl, 1896-1936, at 9198 (2001); see also Cheryl D. Hicks, Confined to Womanhood: Women, Prisons, and Race in the State of New York, 1890-1935, at 62-73 (1999) (unpublished Ph.D. dissertation, Princeton University) (on file with author) (describing Matthews, the first woman 
thews's concern for black women in New York, and specifically black prostitutes, mirrored the concerns of other black reformers who worried that mainstream society would take "for granted that all black people-all Afro-Americans[-were] naturally low." ${ }^{42}$ Matthews, as founder of the White Rose Home for black working women, believed that the black elite had a responsibility to address those problems endemic to working-class and poor, black communities. Thus, she and other black New York reformers distinguished themselves from these particular communities. "[T] he public must be convinced that there is another class than is represented by the depraved class commonly met with on the streets and in certain localities. The common standard of life must be elevated. ... Corrective influences must be established in the infested centres."

White reformers' ideas about black people's capacity for reform were influenced by the legacy of southern slavery. For example, while Frances Kellor established the National League for the Protection of Colored Women in New York and other cities in $1906,{ }^{44}$ her turn-ofthe-century investigations of southern criminality shaped her advocacy on behalf of black women and black people. Slavery, according to Kellor, placed blacks "several centuries behind the Anglo-Saxon race in civilizing agencies and processes." ${ }^{45}$ Black families, then, failed to produce stable patriarchal structures as black women had to work outside the home and black men did "not discourage it." ${ }^{46}$ Interestingly, when addressing black women's morality, Kellor noted that interracial sexual relationships between black women and white men continued after slavery as "white men [had] little respect for the sanctity of family life of Negroes, [whereas] they would hesitate to enter the Anglo-

in New York to establish a working girls' home, and her efforts on behalf of black working women in general and southern migrant women specifically).

${ }^{42}$ V.E. Matthews, Some of the Dangers Confronting Southern Girls in the North, Speech at the Hampton Negro Conference (July 1898) (on file with author); see also GAINES, supra note 39, at 158 (arguing that "uplift's moral assumptions of urban pathology reflected a developmental construction of race and class that bestowed on 'better class' blacks an illusory sense of self-importance as it divested poor urban blacks of agency and humanity").

4.3 Matthews, supra note 42.

${ }^{44}$ Ellen FitzPatrick, ENDless Crusade: WOMEN SOCIAL SCIENTISTS AND Progressive REFORM 139 (1990); SALEM, supra note 10, at 182; WeISS, supra note 10, at 15-20.

${ }^{45}$ Frances A. Kellor, EXPERIMENTAL SOCIOLOGY: DESCRIPTIVE AND ANALYTICAL 33 (1901); see also Frances A. Kellor, Some Old Needs of the New South: Changes Which May Lead to a Diminishing of Crime, 10 CHARITIES 439, 439-40 (1903) (outlining methods to reduce criminality among blacks in the South through civilizing "agencies").

${ }^{46}$ KELLOR, supra note 45 , at 171. 
Saxon home." ${ }^{47}$ Here I would argue that after slavery the rape of black women by white men continued, just as black men's ability to protect their wives remained severely limited. Even under the circumstances highlighted by Kellor (white southern men's inappropriate presence and behavior in black homes), she continually questioned black women's virtue: "Negro women are expected to be immoral and have few inducements to be otherwise." ${ }^{48}$ Thus, as an advocate for black women's protection in New York, Kellor believed that slavery, unequal power, and gender relations in the South limited all black women's capacity for moral character and reform.

Kellor and other white reformers generally assumed that black working-class communities had no sense of moral propriety. In 1911, white reformer Jane Addams of Chicago's Hull House argued that "[o]ne could easily illustrate [the] lack of inherited control" among blacks, especially when comparing "the experiences of a group of colored girls with those of a group representing the daughters of Italian immigrants, or of any other South European peoples." ${ }^{\text {.49 }}$ She explained that, in particular, Italian mothers "seldom [gave their daughters] permission to go to a party in the evening, and never without chaperonage." For Addams, Italians represented the "social traditions which [had] been worked out during centuries of [European] civilization," meaning that these "new groups [had the capacity to be] assimilated into civilization." Bl Black women, however, were without this "protection" of social restraint and, as a result, "yield[ed] more easily to the temptations of a city than any other girls." implicit contention revealed that while she sought to assimilate immigrants, their behavior, however problematic, stemmed from a civilization with roots in European culture that blacks, because of their African descent and the legacy of American slavery, simply did not possess. ${ }^{53}$

${ }^{47}$ Id.; see also Kellor, supra note 45 , at 440 ("The attitude of southern white men toward negroes' homes must be changed before the morality can be measurably improved. There must be an increased respect for its sanctity, and this will, in turn, raise the negro to the standard required.").

${ }^{48}$ KELLOR, supra note 45 , at 171 .

${ }_{50}^{49}$ Jane Addams, Social Control, THE CRISIS, Jan. 1911, at 22, 22.

${ }^{50} I d$.

${ }^{51} \mathrm{Id}$.

${ }^{52} I d$.

${ }^{53}$ Id. See generally LASCH-QuinN, supra note 40, at 11-23 (discussing settlement leaders' views of blacks in the early twentieth century). 
These perceptions of black people and black women influenced the ways in which reformers used the wayward minor laws to compensate for what they perceived as inadequate black parenting. In particular, reformers saw delinquent black women as troublesome because their working-class families lacked both the ability and the authority to address vice as it related to their female relative's behavior. The segment of working-class black family members who used the wayward minor statutes to deal with their fears that female relatives were "in danger of becoming morally depraved" found that their own behavior, as working-class and black family members, was also heavily questioned. As discussed in the next Part, however, such scrutiny failed to translate into appropriate or consistent criminal justice services for their young female members, such as probation or their admission into state-sanctioned private reformatories.

\section{BLACK WORKING WOMEN AND THEIR FAMILIES}

Black families were not, and are not, monolithic entities but had, and still have, their own make-ups and aspirations. Black families had internal differences, and inmate case files from Bedford reveal these differences and indicate that they grappled in various ways with the behavior of their female kin. The fifteen surviving incorrigibility and wayward minor cases of young black women sentenced to Bedford provide a useful lens through which to address the disparate conceptions and definitions of appropriate standards of conduct held by black working-class women and their families. ${ }^{55}$

${ }^{54}$ E.g., Act of Apr. 21, 1920, ch. 295, \$ 1, 1920 N.Y. Laws 848, 848; see also supra note 24 and accompanying text (discussing the law's use of the "in danger of becoming morally depraved" phrase).

${ }^{35}$ For a list of the case files included in this study, see supra note 14. I should note that while I have included Inmate Number 4059 , she was not officially charged under the wayward minor statutes. She was arrested on the complaint of her father because she was incorrigible. See Letter from Gladys Mendum, Agent, Rockland County Branch of the State Charities Aid Association, to Amy M. Prevost, New York State Reformatory Worker, Church Mission of Help 1 (Oct. 13, 1926) (on file with Bedford Hills Files, Inmate No. 4059) [hereinafter Letter from Agent to Reformatory Worker, Inmate No. 4059] ("In March, 1926, [the father] called me and asked that something be done with [his daughter] as she [was] pregnant, expecting to be confined about June, and had been running out nights with different men."). A resident of upstate New York, she was committed under a vagrancy-prostitution charge. History Blank (Apr, 8, 1926) (on file with Bedford Hills Files, Inmate No. 4059) [hereinafter History Blank, Inmate No. 4059]. In Ruth Alexander's study of female delinquency in New York, she notes that

the [incorrigible girl] laws did not apply to adolescent females beyond the boundaries of New York City [until 1923 when they became the wayward minor laws], but by the late nineteenth and early twentieth centuries, Upstate 
The women charged with incorrigibility and the families that sought state intervention represented the diversity of New York's black working class. ${ }^{56}$ Ranging in age from sixteen to twenty-two, these young women were natives of northern states (New York, New Jersey, and Massachusetts), southern states (South Carolina, North Carolina, and Maryland), Washington, D.C., and the British West Indies. As evidenced by their varied backgrounds, some of the families were familiar with urban life, but others were still adjusting to New York City. Each woman received education past the fourth grade and was employed at the time of her arrest as a domestic, laundress, or factory worker. Most had been committed by both parents, single mothers or fathers, or extended family members (grandmothers, aunts, sisters, and cousins), who were usually legal guardians. These family members worked primarily in personal service positions and in factories. Only two of these women experienced some type of juvenile institutionalization before reaching Bedford. ${ }^{57}$ The women and their families' religious denominations included Baptists, Catholics, Methodists, Pentecostals, Presbyterians, and Seventh Day Adventists. Most families struggled to maintain modest homes, while others were considered financially "above the average [for] colored people,": and so respectable within their communities.

families occasionally made creative use of the local and state laws on vagrancy, disorderly conduct, and petit larceny to secure the commitment of rebellious girls to the state's reformatories.

ALEXANDER, supra note 12, at 50. For further discussion on how the wayward minor laws affected parents and young women in New York, see id. at 51-52.

${ }^{56}$ The summary of the data that follows is from the fifteen case files referred to supra note 14.

${ }^{57}$ See History Blank (Feb. 13, 1923) (on file with Bedford Hills Files, Inmate No. 3374) [hereinafter History Blank, Inmate No. 3374] (indicating that the young woman had been committed at the Sojourner Truth Home, the Salvation Army, and the Kingston Avenue Hospital); History Blank (Mar. 8, 1923) (on file with Bedford Hills Files, Inmate No. 3387) (noting that the inmate had spent several years at the Wayside Home and at Randall's Island).

${ }^{58}$ History Blank, Inmate No. 3476, supra note 1; cf. Statement of Girl (June 29, 1917) (on file with Bedford Hills Files, Inmate No. 2486) [hereinafter Statement of Girl, Inmate No. 2486] ("Father has always worked steadily [as a bricklayer] and for many years mother has done janitress and laundry work so that the family income has been more than sufficient."); Statement of Girl (Aug. 8, 1917) (on file with Bedford Hills Files, Inmate No. 2503) [hereinafter Statement of Girl, Inmate No, 2503] (indicating the inmate's belief that she "had a very good home with [her foster parents] and ... never wanted anything she did not get"); Church Mission of Help Summary for Bedford Files (June 7, 1926) (on file with Bedford Hills Files, Inmate No. 4107) [hereinafter Church Mission of Help Summary, Inmate No. 4107] (describing the "excellent," "clean," and "comfortable" home in which the woman lived). 
Inmate records also illustrate that working-class black families ranked themselves within their neighborhoods, the black working class, and wider New York City communities. Black relatives concerned about the level of morals and respectability within their communities often attempted to move out of black neighborhoods when the community seemed threatened by urban vice. Keenly aware of the moral dangers young black women faced on a daily basis, especially as most black neighborhoods housed saloons, dancehalls, gambling, and prostitution, black working-class families were very concerned with protecting the reputations and monitoring the activities of their young women. ${ }^{59}$ This concern influenced how family members understood and responded to their positions within particular neighborhoods.

Family members sometimes believed that living in predominantly black neighborhoods presented young female relatives with a number of vices seemingly not evident in white, and primarily immigrant, communities. Family members' perceptions coincided with the reality of mainstream reform efforts, which, as historian Kevin Mumford notes, focused on moving vice out of white neighborhoods but ignored or failed to address vice immediately when it migrated to predominantly black neighborhoods. ${ }^{60}$ When they could, as some cases suggest, black families moved to what they deemed to be more respectable neighborhoods. One seventeen-year-old woman explained that her parents "always tried to get in a good neighborhood for her sake" and that she had "never lived in a distinctly colored neighborhood." ${ }^{62}$ Another sixteen-year-old inmate who lived in a predominantly Italian-American neighborhood explained that her mother

${ }^{59}$ For references to the connections between black neighborhoods and vice, see JoHN D'Emilio \& ESTElle B. Freedman, intimate Matters: A History of SEXUALITY IN AMERICA 199 (1988); GAINES, supra note 39, at 158; KEVIN J. MUMFORD, INTERZONES: BLACK/WHITE SEX DISTRICTS IN CHICAGO AND NEW YORK IN THE EARLY TWENTIETH CENTURY 19-35 (1997). See also Elsa Barkley Brown \& Gregg D. Kimball, Mapping the Terrain of Black Richmond, in THE NEW AFRICAN AMERICAN URBAN HISTORY 66 (Kenneth W. Goings \& Raymond A. Mohl eds., 1996) (addressing, in part, how blacks in Richmond, Virginia, dealt with issues of morality, respectability, and urban space).

${ }^{60}$ See MUMFORD, supra note 59, at 22-28 (documenting the "quiet" migration of vice from white to predominantly black neighborhoods in Chicago and New York City and the initial lack of response by the police and social reformers to this migration).

${ }^{61}$ Statement of Girl, Inmate No. 2486, supra note 58.

62 Author's Notes, Home Conditions: Information of Mother (July 25, 1917) (original on file with Bedford Hills Files, Inmate No. 2486) [hereinafter Home Conditions, Inmate No. 2486]. 
"always tried to live in a good neighborhood, so that she would not meet bad girls." 63 In describing her neighborhood as a "[v]ery good residence section in [the] Bronx," an inmate reinforced the conception that black neighborhoods were problematic by emphasizing that " $\mathrm{t}$ ] here [were] no colored people in this vicinity except one colored janitress [on the] next block." that vice was not exclusive to black neighborhoods when she disclosed that having moved into a "bad neighborhood, where a great many Italians of a poor class lived," her family left as a soon as they could. ${ }^{65}$ Indeed, when it was possible, family members moved to what they perceived to be better neighborhoods, where they realized that equating white working-class neighborhoods with better neighborhoods was, in large part, inaccurate.

The negative stigmas attached to the black neighborhoods in which most black women lived increased their relatives' concerns about their moral and physical well-being. While Jane Addams and other white reformers believed that the prevalence of red-light districts in black neighborhoods created disastrous conditions for young black women because their families were, in Addams's estimation, "least equipped with social tradition [and] forced to expose [their] daughters to the most flagrantly immoral conditions the community permit[ted], ${ }^{, 66}$ the case files of young women living in black neighborhoods tell another story. One twenty-year-old inmate noted that while she lived in a good neighborhood, her social outings (movies and public dances) were contingent upon her mother's presence. ${ }^{67}$ Another eighteen-year-old revealed that she was "[b]rought up strict." 68 Living in Harlem, her behavior was closely monitored by her guardian siblings who never allowed her to "play in [the] streets" but encouraged her to attend activities at the local Young Women's Christian Association (YWCA). ${ }^{69}$ She also revealed that in order to attend movies or public dances, various of her older sisters had to accompany her. $^{70}$

${ }^{63}$ Statement of Girl, Inmate No. 2503, supra note 58.

${ }^{64}$ Statement of Girl, Inmate No. 2486, supra note 58.

${ }^{65}$ Home Conditions, Inmate No. 2486, supra note 62.

${ }^{66}$ Addams, supra note 49, at 22.

${ }^{67}$ History Blank (July 19, 1924) (on file with Bedford Hills Files, Inmate No. $3708)$.

${ }^{68}$ History Blank (Aug. 2, 1924) (on file with Bedford Hills Files, Inmate No. 3711) [hereinafter History Blank, Inmate No. 3711].

${ }_{70}^{69}$ Id.

${ }^{70} \mathrm{Id}$. 
Indeed, working-class families' concerns about their young women's growth and development were shaped by their specific perceptions of their neighborhood's reputation, regardless of whether they lived in or near white or black neighborhoods. Yet in those instances when female relatives rejected their family members' attempts to protect them and to guide them through established rules and regulations, some relatives made their private concerns about these young women public and embraced the tenets of the wayward minor laws.

\section{Probation, Local ReFormatories, AND BEDFord}

Once they "entered" a complaint against their female kin, most families, black and white, believed that the young women would be reprimanded in court, given probation, or, in extreme cases, sent to a local reformatory. Many assumed, as did the parents of one seventeen-year-old, that the "scare of bringing her into court would [have been] enough punishment." Black women, however, failed to receive probation at the same rate as white women and were often rejected from mainstream social welfare efforts because of the discriminatory policies of court officials and local reformatories. Thus, the justice system handled black women's minor moral and social transgressions differently than those of their white counterparts, as the support mechanisms that encouraged preventive rehabilitation rather than punitive incarceration were less available to black women.

Even though reformers, and the courts that carried out their objectives, supported the criminalization of young women's behavior, they advocated probation and generally discouraged treatment within a state (and particularly a custodial) institution. This is because they believed that these women were too old for juvenile court but too young to be sentenced with adult offenders. ${ }^{72}$ Reformers advocated probation because they believed that custodial sentences with "confirmed prostitutes, shoplifters, and petty thieves" offered little help to an adolescent girl. ${ }^{73}$ Probation addressed delinquent behavior by suspending court sentences (or by not sentencing at all) and releasing

7 See Staff Meeting (Aug. 11, 1917) (on file with Bedford Hills Files, Inmate No. 2486) [hereinafter Staff Meeting, Inmate No. 2486] (providing Administrator Dawley's description, based on an interview with the parents, of their beliefs).

${ }^{72}$ See TAPPAN, supra note 19, at 151 (describing how courts tried to minimize the number of young women committed to institutions with older women due to "the possible deleterious effect of association with older and habitual offenders").

${ }^{79}$ Id. 
the offender without incarceration. ${ }^{74}$ Deemed by reformers as the best solution for young women, probation treated minors as wayward "without suffering the stigma of the conviction of crime." W5 Women were allowed to live with their families but were under the supervision of a probation officer in order to test "whether [they could] live in [a] free society without breaking the law." ${ }^{76}$

\section{A. Impediments to Providing Black Women with Probation}

Probation posed a number of problems, however, for black women. In 1914, an investigative report of the Jefferson Market Night Court, undertaken by the National League on Urban Conditions among Negroes, found that probation officers appointed by the court, local jurisdictions, or local religious organizations often neglected black women's cases. ${ }^{77}$ The report noted that "[a]lthough provision [s] ha[d] been made at the Night Court for the maintenance of a Jewish, a Protestant, and a Catholic worker, ... very little protective, preventive, and reformative work [was] being conducted among [black] women." ${ }^{78}$ Probation officers of various religious affiliations, the report concluded, dealt with black women on a limited basis because their "chief interest" was the supervision of white women. ${ }^{79}$ Thus, probation officers privileged the needs of white women over black women.

The availability of probation was also a problem for black female offenders, often resulting in a higher number of black women incarcerations in state and custodial institutions. In fact, a study of female delinquents in New York, published in 1920, found that probation was

\footnotetext{
${ }^{74}$ See JOHn Lewis Gillin, CRIminology AND PENOlogy 807 (1926) (detailing the probation system: either the "sentence is suspended and the man is put on probation [or] he is put on probation without sentence having been passed").

${ }^{75}$ Willoughiby CYRus Waterman, Prostitution and ItS REPRESSION IN NEW YORK CITY, 1900-1931, at 40 (1932).

${ }^{76}$ Gillin, supra note 74 , at 807 . For more on the probation of women, see $i d$. at 807-50.

${ }^{77}$ See Author's Notes, Carietta V. Owens, Investigation of Colored Women at Night Court, from June 8th to August 8th (1914) (original on file with Rare Books and Manuscripts Division, N.Y. Public Library, Astor, Lenox and Tilden Foundations, Records of Committee of Fourteen (Committee of Fourteen), Box 63) [hereinafter Owens, Investigation of Colored Women at Night Court] ("The Protestant, Catholic, and chief probation officer come in contact with colored women and to some extent help them; but their chief interest is centered in the white women.").

$$
{ }^{78} \begin{aligned}
& l d . \\
&
\end{aligned}
$$
}


largely unavailable to black women ${ }^{80}$ because of the "meager facilities for supervising colored girls ... [and because] several of the private institutions in the city refus[ed] to take colored women."

Superintendents of local reformatories cited several reasons for their policies toward black women. While the law did not designate institutional care based on race, administrators' ideas about black people and sexuality pervaded reports that justified the exclusion or separation of black from white (both native and immigrant) women. Administrators' explanations primarily stemmed from concerns about how black women's sexual and criminal nature would affect white women. Thus, the anxiety about delinquent working women was temporarily and conveniently shifted to the race problem.

One rationalization for rejecting black women from private institutions was the fear that interracial, same-sex relationships would develop. One superintendent explained that "the colored girls [possess] an unwholesome physical attraction for the white girls and ... it is better for both races that they be kept apart." ${ }^{, 22}$ Within an institutional setting, the commonplace, and usually southern, fear of black men because of their perceived sexual threat to white women became displaced by anxiety that the mere presence of black women caused social disorder among a white inmate population. ${ }^{83}$ This view did not take into account the real existence of same-sex relationships and the problems administrators encountered when white inmates actively sought out relationships with black women. ${ }^{84}$

${ }^{80}$ See MAbel Ruth Fernald et AL., A Study of WOMEn Delinquents in NeW YORK STATE 169 tbl.40 (Patterson Smith 1968) (1920) (providing incarceration and probation rates for native-born black and white women).

Id. at 171 .

${ }^{82}$ Owens, Investigation of Colored Women at Night Court, supra note 77 (relaying the beliefs of Sister Gertrude, Superintendent, House of Mercy).

${ }^{83}$ I would like to thank Tera Hunter for pushing me to address this crucial point.

${ }^{84}$ See AlEXANDER, supra note 12, at 96 (noting that interracial, lesbian relationships between inmates were a particularly significant form of inmate subculture); Estelle B. Freedman, The Prison Lesbian: Race, Class, and the Construction of the Aggressive Female Homosexual, 1915-1965, 22 FEMINIST STUD. 397, 400 (1996) (“[A]ssigning the male aggressor role to Black women and preserving a semblance of femininity for their white partners racialized the sexual pathology of inversion."); Regina G. Kunzel, Situating Sex: Prison Sexual Culture in the Mid-Twentieth-Century United States, GLQ: J. LESBIAN \& GAY STUD., May 2002, at 253, 261-62 (outlining various investigators' explanations "for the attraction of white girls to black girls"); Margaret Otis, A Perversion Not Commonly Noted, 8 J. ABNORMAL PSYCHOL. 113, 114 (1913) (excerpting notes written by reform school girls involved in same-sex, interracial relationships). For a discussion of interracial lesbian relationships at Bedford, see Hicks, supra note 41, at 177-214. 
Another reason private institutions rejected black women was the possible violent antagonisms generated among an interracial inmate population. Although the House of Good Shepherd had a separate "home for colored girls under sixteen, it [did] not [accept] those over sixteen, claiming that the white girls [would] make it unpleasant for the colored girls, and that they could not afford to mix them." ${ }^{85}$ Arguments such as these implicated black women's mere presence as disruptive to the real objective of rehabilitating wayward and rebellious young (white) girls.

The exclusionary policies of private institutions limited black women's ability to benefit from state-sanctioned rehabilitative services. Consider the case of an eighteen-year-old woman whose probation officer believed that her behavior might improve if she were removed from her "mother's charge." The officer acknowledged the limitations imposed on black women when she noted in 1917: "The Episcopal House of Mercy cannot receive any colored girls at present and the Magdalen Home does not receive them at all; the only place that defendant could be sent would be to [Bedford]. ${ }^{87}$ In 1913, The Survey, a leading periodical of social progressivism, revealed, in its support of the Sojourner Truth Home (a local home for young, delinquent black women), that the odds for young blacks and particularly young black women of being admitted to private reformatories were "at least five to two that they would find no door open to them." 88

Black women were not completely denied admittance into all local reformatories, but their reception depended largely on the subjective decisions of particular administrators rather than the policies of local reformatories. In 1911, Ellie Walls, a National Urban League Research Fellow and a member of the Committee on Urban Conditions Among Negroes at the New York School of Philanthropy, noted that

${ }^{85}$ Owens, Investigation of Colored Women at Night Court, supra note 77.

${ }^{86}$ See Information Concerning the Patient (June 6, 1917) (on file with Bedford Hills Files, Inmate No. 2466) (reprinting the probation officer's report). While Inmate Number 2466 was not convicted as a wayward minor, see id. (noting that she was charged with "larceny of [a] gold bracelet valued at $\$ 25 ")$, her case shows the limited probation options available for black women.

${ }^{87} I d$. There is some question as to whether the inmate received probation rather than a sentence at Bedford. See Information Concerning the Patient (May 8, 1917) (on file with Bedford Hills Files, Inmate No. 2466) (suggesting that she was not given probation because her probation officer found it "impossible ... to stay for all of [the] trial and so [the judge sentenced the inmate] to Bedford for three month").

${ }^{88}$ Sojourner Truth's Work Marching On, THE SuRVEY, Dec. 13, 1913 (on file with Division of Behavioral Science Research, Carver Research Foundation, Tuskegee Institute, Tuskegee, Ala., Tuskegee Institute News Clipping File (Tuskegee News File), Reel 2). 
the "House of Good Shepherd and the House of Mercy, which formerly received colored girls, no longer accepts them, although these institutions describe themselves as being open for the help of all friendless women, regardless of race, color or religion." ${ }^{89}$ The inconsistent policies of private reformatories consequently made commonplace those instances where one black woman was refused admittance but another woman was admitted for a similar charge. ${ }^{90}$

Limited resources within various black communities also exacerbated the problem of probationary and local institutional care for black women." There were few workers dedicated to working with delinquent black women. Grace Campbell represented one member of the small group of overextended reformers working with delinquent black women. Her work with multiple reform organizations, as well as state and municipal institutions, demonstrated her commitment to the rehabilitation of young black women. ${ }^{92}$ As Superintendent of the Empire Friendly Shelter for Friendless Girls (a home for delinquent black women), Campbell also worked as a black probation/parole officer, addressing the needs of female offenders in New York City jails, Bedford, and the New York State Prison for Women at Auburn. ${ }^{93}$ Additionally, the institutions that did exist for black delinquent women, like the Sojourner Truth Home and the Empire Friendly Shelter for Friendless Girls, were underfunded, overcrowded, and short lived. ${ }^{94}$

${ }^{89}$ Conference of Social Workers: Two Important Sessions Held Monday at United Charities Building, N.Y. ACE, Dec. 7, 1911 (on file with Tuskegee News File, Reel 1).

${ }^{90}$ For example, in 1917 the House of Good Shepherd refused admittance to one black woman, Verified History (July 1917) (on file with Bedford Hills Files, Inmate No. 2486) [hereinafter Verified History, Inmate No. 2486], but then in 1922 admitted another black woman who had committed a similar offense, History Blank (J uly 18 , 1924) (on file with Bedford Hills Files, Inmate No. 3705).

(9) Although there is scant information regarding black probation officers and probationary care in black communities, for some useful information, see ANNE MEIS KNUPFER, REFORM AND RESISTANCE: GENDER, DELINQUENCY, AND AMERICA'S FIRST JUVENILE COURT 59-64 (2001); ANNE MEIS KNUPFER, TOWARD A TENDERER HuMANITY AND A NOBLER WOMANHOOD: AFRICAN AMERICAN WOMEN'S CluBS IN TURN-OF-THECENTURY CHICAGO 66-67 (1996).

${ }^{42}$ See Hicks, supra note 41, at 79 (“[W]hile running the [Empire Friendly Shelter for Friendless Cirls], continuing her probationary work, and serving one year as a social investigator for the Board of Child Welfare, Campbell was appointed parole officer for the Parole Commission of New York City.").

${ }^{93}$ Id. at 77-79. For more on Grace Campbell, see WINSTON JAMES, HOLdinG

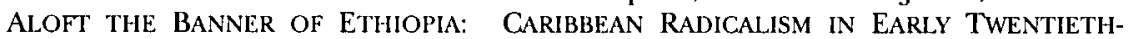
CENTURY AMERICA 174-77 (1998); Hicks, supra note 41, at 73-82.

${ }^{94}$ See, e.g., Appeal for Negro Magdalens, EVEniNG Globe (N.Y.), Apr. 6, 1917 (on file with Tuskegee News File, Reel 7) (appealing for money for the Empire Friendly Shelter for Friendless Girls and noting that it was "sadly in need of funds"); Home Reorgan- 


\section{B. Segregated Rehabilitation}

There were a small number of white reformers who supported overall attempts to rehabilitate delinquent black women. However, these reformers envisioned change through racial segregation. Many of these initial efforts, like the Sojourner Truth Home, indicated more of a concern for delinquent black women under the age of sixteen." But reformers soon realized that they needed to address not only the younger offenders and their inadequate facilities, but black delinquent women over the age of sixteen. One interracial committee revealed its desire to open a home for delinquent black women. ${ }^{96}$ The organization's efforts stemmed from the fact that the "small and inadequately run House" used for black women was "now entirely without funds to continue the work." need to "establish a Home for friendless and wayward colored girls such as Waverly House and Florence Crittenton House for white girls." "98

Black women needed help as judges and police officers were "at a loss" in deciding what to do with those women who "should not be locked up with criminals" but who "should not be turned out on the streets with no one to care for them." The reformers' push for the new home, which would "be a place of temporary abode where col-

ized, N.Y. AGE, July 24, 1913 (on file with Tuskegee News File, Reel 2) (noting that the Union Rescue Home, "which [was] a temporary home for unfortunate and delinquent colored women and girls," was "badly in need of funds"); In Need of Financial Aid, N.Y. AGE, Oct. 19, 1916 (on file with Tuskegee News File, Reel 5) (describing how Grace Campbell, with the "financial aid received from friends who voluntarily contributed," sustained the only institution for the care of delinquent black girls, the Empire Friendly Shelter for Friendless Girls).

${ }^{95}$ See The Sojoumer Truth House and Its Work: Splendid Accomplishment of Organization for Care of Wayward Girls, N.Y. AGE, Sept. 28, 1916 (on file with Tuskegee News File, Reel 5) ("The lack of suitable temporary quarters for delinquent colored girls under 16 years of age led to the formation, several years ago, of the Sojourner Truth House ....").

${ }^{96}$ See The Problem of a Shelter for Colored Girls (n.d.) (on file with Committee of Fourteen, Box 10) ("Will you help in the effort to establish this Home for the friendless colored girl and put it on a permanent basis?"). Black committee members included Eva Bowles from the Colored YWCA and Fred Moore of the black newspaper, New York Age. Id. Prominent white members included Dr. Katharine Bement Davis, who had been the first Superintendent of Bedford and who had propounded a racially integrated policy during her tenure, Hicks, supra note 41, at 183-84, and Elizabeth Walton from the National League on Urban Conditions Among Negroes, The Problem of a Shelter for Colored Girls, supra.

${ }_{97}$ The Problem of a Shelter for Colored Girls, supra note 96.

${ }^{98} I d$.

99 Id. 
ored girls [could] be cared for under conditions favorable to mental and moral improvement," ${ }^{100}$ both illuminated their concern for black women's rehabilitation and revealed their vision of segregated reform. The committee's black members seemed assuaged by its white members' assistance and concerns despite the white members' promotion of segregation and consistent use of race-based parameters to address the problem of delinquent black women. These white reformers clearly believed that young black women needed the same kinds of reform as white women but that institutional rehabilitation in New York should occur under Jim Crow conditions.

Concerned and frustrated by these kinds of committees, some black reformers, as early as 1913, criticized the racism underlying mainstream reform efforts for delinquent black women. A New York Age editorial, The Sisterhood of Woman, specifically criticized the Conference of Organizations for Assisting Young Women, which included representatives from many local reformatories and institutions that did not accept black women or that did so only on a limited basis. ${ }^{101}$ The Age editorial disagreed with the conference's statement that a proposed home for black women should garner support because "few if any colored girls can or should be received in homes for white girls." Agreeing with the conference's contention that black female offenders needed social services, the editorial argued that if social welfare reformers stopped making racial distinctions in their private and state institutions, there would be no need for a distinct home for black women such as the proposed Sojourner Truth Home for Delinquent Colored Girls. ${ }^{109}$ "We need such a home," the editorial concluded, "because the State of New York and the private charity organizations which receive such delinquent girls at the expense of the county or the State, have deliberately denied to Delinquent Colored Girls [s] isterhood with Delinquent White Girls." ${ }^{104}$

These sentiments were underscored ten years later when another black reformer argued that it was "hard to understand the policy of

${ }^{100}$ Id.

101 See The Sisterhood of Woman, N.Y. AGE, June 12, 1913 (on file with Tuskegee News File, Reel 2) (including, among others, the Church Mission of Help, the Florence Crittenton Mission, the House of Mercy, the Lakeview Home, the Magdalen Benevolent Society, and the New York Probation Association in the list of institutions represented in the conference). 1913).

${ }^{102}$ Id. (quoting a resolution passed by the conference at a meeting on May 16,

${ }_{104}^{109} I d$.

Id. 
the great State and City of New York, willing to spend hundreds of thousands of dollars in the attempt to reform girls, but unwilling to spend a few thousands to protect, help and eventually save the underprivileged colored girl." ${ }^{105}$ A frustrated Mrs. Edwin Horne explained, in the New York Amsterdam News, that young black women needed "sympathy, encouragement, help, direction and guidance." 106 She noted that " $[\mathrm{t}]$ here [were] plenty of such institutions for white girls, but there [was] not one for the unadjusted colored girl."107

Considering reformers' specific concerns regarding black women's inadequate access to rehabilitative services, the long-term consequence of the segregationist practices in New York's criminal justice system was an increased population of young black female inmates in state, rather than local, reformatory institutions. The results of reformers' decisions to assist women based on race reinforced the stereotype that the high numbers of incarcerated black women reflected black women's inherent criminal nature. Consequently, young black women not only dealt with being sent to court for disobedience but also were subjected to harsher treatment in the criminal justice system than their white counterparts. ${ }^{108}$ Black working-class parents

${ }^{105}$ Mrs. Edwin F. Horne, The Problem of the Negro Girl, N.Y. AMSTERDam NEwS, Jan. 31, 1923 (on file with Tuskegee News File, Reel 17).

${ }^{106} \mathrm{Id}$.

107 Id

${ }^{108}$ While Paul Tappan's study, TAPPAN, supra note 19 , covers a later time period (1938 to 1942) than my own study (1917 to 1928), the issue of inadequate criminal justice services for black women in the 1930s clearly suggests that services for black women in my study were meager at best and that this particular issue was longstanding.

The almost utter lack of institutional facilities for the Negro offenders result[ed] in a continuous inequality of treatment in the Court and an inability to deal effectively with these girls, however much the Court [would] do so.... The general social environment [was] certainly no more favorable to Negro probation cases. Until recently the Court lacked any Negro probation officers, although in most years some 30 percent of the cases [were] Negresses.

Id. at 152. This situation mirrored the conditions of black juvenile female delinquents in the New York City Children's Court as well as the circumstances of adolescent black women in the 1930s. Judge Franklin Chase Hoyt, then-Presiding Justice of the Children's Court, summarized the overall response of administrators to black clients:

The situation in regard to the inadequate facilities for institutional care of colored delinquent children is an unfortunate one. The Children's Court is confronted almost daily with its inability to deal constructively with colored children under sixteen years of age who are in need of custodial care by reason of the scarcity of institutions willing to accept such children. The community should be fully informed of these deplorable conditions in order that the colored child may receive its proper share of institutional education and training. It is my hope that this report will help bring about a solution. 
and their kin, who were primarily concerned with the disruptions caused by what they viewed as rebellious young women, were often unaware (until it was too late) of these dire circumstances.

Geraldine Jones's case highlights the dilemmas that many black parents faced when they turned to the State believing the worst-case scenario for their daughters would be probation or a short sentence in a local reformatory. Concerned about Jones's moral welfare, her parents' initial encounter with the criminal justice system occurred when Jones ran away from home with a suspicious black couple (the woman "was known to be a procurer of girls") ${ }^{109}$ who lived in the same rooming house as the Jones family. ${ }^{110}$ When Jones returned home four days later, her father had the couple charged with "white slavery," more commonly used to refer to instances where young women were allegedly forced into prostitution. ${ }^{112}$ Subsequent to this incident and after several disputes with her parents, seventeen-year-old Jones became increasingly harder to manage. ${ }^{113}$ The final straw occurred when she disobeyed her father and stayed out all night with a woman her father claimed had a "reputation [that] was questionable."14 After "ma[king] a complaint against her," he took a police officer to the woman's house, where Jones was found and arrested. ${ }^{115}$

Joint Comm. on Negro Child Study in N.Y. City, A Study of Delinquent and Neglected Negro Children Before the New York City Children's Court 1925, at 24 (1927) (on file with N.Y. State Library, State Education Department, Albany, N.Y., Manuscripts) (quoting Justice Hoyt).

${ }^{109}$ Statement of Girl, Inmate No. 2486, supra note 58.

${ }^{110}$ Verified History, Inmate No. 2486, supra note 90.

111 Id.

112 For information on forced prostitution/"white slavery" and white women, see Ruth Rosen, The Lost Sisterhood: Prostitution in AMERICA 1900-1918, at 112-35 (1982). References to black women in white slavery were uncommon; however, the campaigns against white slavery made an impact on black communities (as demonstrated by the case of Inmate Number 2486). Moreover, black reformers sometimes used the language of white slavery campaigns to stress the need for young black women's protection. See, e.g., S.W. Layten, A Northern Phase of a Southern Problem, 26 AFR. METHODIST EPISCOPAL. CHURCH REV. 315, 324 (1910) (relaying the National League for the Protection of Colored Women's objectives and noting that they dealt with the "black side of white slavery").

${ }^{113}$ See Information Concerning the Patient: Information of Mother (July 25, 1917) (on file with Bedford Hills Files, Inmate No. 2486) [hereinafter Information of Mother, Inmate No. 2486] ("Since that time she has been uncontrollable, has been impudent, saucy and determined to have her own way, and she has indulged in violent outbursts of temper.").

${ }_{115}^{114}$ Verified History, Inmate No. 2486, supra note 90.

115 Id. 
Initially, Jones was sentenced to the House of Good Shepherd, ${ }^{116}$ a Catholic reformatory seen as more of a reform school than a reformatory prison and, therefore, having less of a stigma attached to it. ${ }^{117}$ After Jones's parents consented to her commitment at the local reformatory, however, they were notified that her commitment had been changed to Bedford because at that time the House of Good Shepherd did not accept black women. ${ }^{118}$ Jones's parents "fe[lt] very badly because she was sent" to Bedford. ${ }^{119}$ Not wanting to be seen as "an object of charity," parent; however, their simple plan of going to the courts to intimidate their daughter backfired. Jones's father explained that "he did not intend to have her sent away but simply wanted to scare her so she would know she must obey him." ${ }^{21}$ Jones's parents were unprepared for how the State's ruling, coupled with institutional racism, would fail to buttress their assertion of parental authority. ${ }^{122}$

\section{Bedford}

Committed for the same offenses, young white and black women did not have similar support from the State in shaping their rehabilitation. In light of the inadequate probation services and segregationist policies of local reformatories, many black women were automatically sent to Bedford. A well-respected state rehabilitative facility, Bedford represented one of the final stages in the reform process of young women who violated probation or the policies of private reformatories. When sent to Bedford, white women usually arrived with a number of probation violations and had already spent time in local reformatories. On the other hand, black women usually were sent to

116 Id

117 For more information on the House of Good Shepherd, see Suellen Hoy, Caring for Chicago's Women and Girls: The Sisters of the Good Shepherd, 1859-1911, 23 J. URB. HisT. 260 (1997).

${ }^{118}$ Verified History, Inmate No. 2486, supra note 90. Jones's parents failed to show up at her second court hearing (after she was sent to Bedford) because they were not notified. Information Concerning the Patient: Information of Father (J uly 30, 1917) (on file with Bedford Hills Files, Inmate No. 2486) [hereinafter Information of Father, Inmate No. 2486].

${ }^{119}$ Verified History, Inmate No. 2486, supra note 90.

${ }^{120}$ Information of Mother, Inmate No. 2486, supra note 113.

${ }^{121}$ Verified History, Inmate No. 2486, supra note 90.

122 See Information of Father, Inmate No. 2486, supra note 118 ("He feels that now she has been taught a lesson and will appreciate her home if she is permitted to return to it."). 
Bedford without the benefit of probation or a previous sentence in a local reformatory. In one instance, when Bedford administrators discussed admitting an inmate who had no prior offenses, they acknowledged that instead of confinement the black woman "would have been given probation if there [were] more adequate provision[s] for colored girls."

In its early years, Bedford's reputation was based on the idea that it could successfully reform young wayward women. ${ }^{124}$ While Bedford's focus and objectives centered on training and rehabilitating adolescent women, the institution held moral offenders along with misdemeanants and a small number of felons. ${ }^{25}$ Beginning in 1920 , those women deemed "unfit[] to benefit by the discipline and training" of local reformatories, ${ }^{126}$ such as the Wayside Home and the House of Good Shepherd, were also committed to Bedford. Thus, rather than obtaining care that met the objectives of the wayward minor laws, a woman sent to Bedford after 1920 under a wayward minor charge was held to the same regulations as the Bedford residents who had committed more serious offenses.

Families often believed that their female relatives would benefit from Bedford's reform policies. In letters to the superintendent, a number of family members praised the institution's emphasis on rehabilitating young women. One mother, inquiring about her daughter's lack of correspondence, told Superintendent Helen Cobb that she understood her daughter was "well taken [care] of with [Bedford's] good people." ${ }^{127}$ Ironically, many parents, as well as black reform organizations, like the National Urban League, pushed for higher numbers of black women to be admitted into Bedford because even a Bedford commitment was not guaranteed. ${ }^{128}$ In light of the 2480).

${ }^{23}$ Staff Meeting (Aug. 3, 1917) (on file with Bedford Hills Files, Inmate No.

124 See Estelle B. Freedman, Their Sisters' Keepers: WOMEN'S Prison Reform IN AMERICA, 1830-1930, at 138 (1981) (noting that Bedford "suffered from its own good reputation," becoming "a popular place to send 'incorrigible' women"). For a discussion of Bedford's innovative reform methods, see id. at 131-34; NICOLE HAFN Rafter, Partial Justice: Women, Prisons, and Social Control 69-74 (2d ed. 1990).

${ }^{125}$ RAFTER, supra note 124 , at 36.

${ }^{126}$ Act of Apr. 21, 1920, ch. 295, § 5, 1920 N.Y. Laws 848, 850.

${ }^{127}$ Author's Notes, Letter from Inmate's Mother to Helen Cobb, Superintendent, Bedford (Oct. 28, 1918) (original on file with Bedford Hills Files, Inmate No. 2503).

${ }^{128}$ See Minutes, Committee for Protection of Women (Jan. 6, 1913) (on file with Library of Congress, Collections of the Manuscript Division, Washington, D.C., National Urban League Papers (National Urban League Papers)) ("RESOLVED . . . that a 
problems black women faced with limited probation and inconsistent access to private, local reformatories, Bedford, in many ways, offered a rehabilitative setting that most black women would not have received otherwise. It seems highly unlikely that black parents and guardians would have filed complaints against, and in some cases refused probation of, their female relatives if they knew the full context of rehabilitative services available to young black women. In the end, Bedford represented what black families saw as the best solution for dealing with rebellious and easily influenced young women.

\section{WAYWARD MINOR CASES}

Believing that imprisonment would provide the discipline and training needed to reinforce their authority and protect female relatives from dangers in the city, especially when these young women asserted their social and economic independence, some black families went to the State to reinforce their standards of morality and respectability.

Varying forms of parental disobedience, from broken curfews to out-of-wedlock pregnancies, headed the list of wayward minor commitments. Yet, black working-class families did not immediately see the State as the solution to their problems. Parents and kin had a clear sense of what they expected from young women, as well as the State, when they had their female relatives arrested. Inmate case files suggest that it was only when preventive measures and home discipline failed that working-class families turned to state laws to address those issues that created the most conflict between relatives and young women-labor, leisure, and sexual propriety. ${ }^{129}$

\footnotetext{
letter be written to the Board of Management of Reformatory Institutions, asking them to take action to obtain additional accommodation at ... Bedford for colored delinquents ...."); Minutes, Committee for Protection of Women (Feb. 3, 1913) (on file with National Urban League Papers) ("The Chairman read a letter from Miss Katherine Davis, [Superintendent] of [Bedford], in which it was stated that additional space was urgent... and in which she asked that the Committee co-operate... in urging upon the legislature that suitable appropriations be made.").

${ }^{129}$ See ODEM, supra note 12, at 159 ("[P] arents hoped that the court would help strengthen their flagging authority over the social and sexual activities of their teenage daughters [at the same time that] young women and girls . . . began to challenge traditional family expectations and to resist their parents' attempts to control their labor, free time, social interactions, and sexuality."); $c f$. ELIZABETH LUNBECK, THE PSyChIATRIC PERSUASION: KNOWLEDGe, Gender, AND POWER IN MODERN AMERICA 8283 (1994) (noting that "intrafamilial policing [was] responsible for bringing the largest group of patients" to the attention of psychiatrists in early-twentieth-century Boston); Michael Willrich, The Two Percent Solution: Eugenic, Jurisprudence and the Socialization of
} 
While this Article focuses on the actions and responses of black working-class relatives, the voices of the women charged with violating the wayward minor laws reveal a mixed reception to their Bedford commitments. Even though the case files examined here fail to reveal an in-depth response of female offenders to their commitments, young women held differing views of their imprisonment. While institutionalized in Bedford, many inmates came to understand their relatives' reactions, admitted fault, and worked to improve themselves. Other inmates, however, were angered by their imprisonment and felt betrayed by their families' actions. For example, one woman, when she learned that the aunt who had her committed wanted to reestablish their relationship, dismissively responded: "I'm able to take care of my self now. And also made a wom[a]n of myself. I know [right] from $[w]$ rong. [I'm] not a child any more."

As a result, case files illustrate the range of working-class black family members' everyday concerns rather than the concerns of the wayward minors. Young women were considered in "danger of becoming morally depraved" when they disregarded their curfews, became truant, spent too much time with their boyfriends, experienced conflicts with family members that led to their voluntarily leaving the home, or when their family members reached a general consensus that they had become unmanageable. ${ }^{191}$ Thus, while regulating young women's behavior addressed working-class relatives' desires to protect and to enforce morality, these commitments were also used to address intrafamilial disputes regarding personal conflicts, a young woman's assertion of independence, and how a young woman's behavior could negatively affect the financial stability of the family.

Constance Mimms's case suggests how conflicts with extended family members could be construed as respectability battles and lead to a young woman's arrest. Mimms, a sixteen-year-old native of South Carolina, was arrested on charges filed by her cousin, who subse-

\footnotetext{
American Latw, 1900-1930, 16 LAW \& HiST. Rev. 63, 102 (1998) ("Feebleminded commitment case files from the Municipal Court [of Chicago] reveal a pattern of family self-policing similar to that ... in juvenile courts, where working-class parents called upon the state to help them regulate their 'unruly' children. Petitioners in feebleminded cases were overwhelmingly parents or family members ....").

${ }^{130}$ Author's Notes, Letter from Inmate to Amos T. Baker, Superintendent, Bedford (Jan. 5, 1925) (original on file with Bedford Hills Files, Inmate No. 3365).

${ }_{131}$ The following inmates were committed for some or all of these reasons: Inmate Numbers 2486, 2503, 2682, 3365, 3374, 3387, 3476, 3708, 4028, and 4107 .
} 
quently moved to North Carolina for a teaching position. ${ }^{132}$ Orphaned at the age of six, Mimms lived with one aunt in Florida, but after turning fifteen she moved to New York and lived with another aunt. ${ }^{1.33}$ Convinced she was being treated unfairly, Mimms ran away from home. ${ }^{134}$ Later she complained that, on several occasions, "her aunt took her money to buy clothing for her cousin." ${ }^{185}$ Initially working as a family's live-in domestic, she eventually turned to day work ${ }^{136}$ and moved in with a female friend. ${ }^{137}$ Mimms's mixing with "a bad crowd of girls and boys" led her cousin to report her behavior, and she was arrested by the police on incorrigibility charges. ${ }^{138}$

Another case illustrates the difficult transitions that surviving spouses and daughters experienced after the death of a parent. Seventeen-year-old Mabel Smith was institutionalized by her father several times before her Bedford commitment. ${ }^{199}$ Her family-her father and two younger sisters-moved from Boston to New York City after her mother's death. ${ }^{140}$ During this transition, Smith's disputes with her father increased and her behavior, in his estimation, deteriorated; Smith's father twice took her to court for incorrigibility. ${ }^{141}$ She was given probation on her first charge, and on her second she was sent to the Sojourner Truth Home, ${ }^{142}$ a short-lived local institution for delinquent black girls established by the National Urban League. After the next incorrigibility charge filed by her father, she was sent to the Sal-

${ }^{132}$ History Blank (Feb. 8, 1923) (on file with Bedford Hills Files, Inmate No. 3365) [hereinafter History Blank, Inmate No. 3365].

${ }^{133}$ Recommendation for Parole (Aug. 7, 1923) (on file with Bedford Hills Files, Inmate No. 3365) [hereinafter Recommendation for Parole, Inmate No. 3365].

${ }^{134}$ History Blank, Inmate No. 3365, supra note 132.

195 Author's Notes, Admission Record (Feb. 1, 1923) (original on file with Bedford Hills Files, Inmate No. 3365).

${ }^{136}$ Day work means that a domestic worker is a household worker who comes to her job everyday instead of living at the family's home. ELIZABETH CLARK-LEWIS, LIVING IN, LIVING OUT: AFRICAN AMERICAN DOMESTICS AND THE GREAT MIGRATION 147-72 (1994).

${ }^{137}$ History Blank, Inmate No. 3365, supra note 132.

138 Recommendation for Parole, Inmate No. 3365, supra note 133.

${ }^{139}$ See History Blank, Inmate No. 3374, supra note 57 (indicating that Smith was committed at the Sojourner Truth Home, the Salvation Army, and the Kingston Avenue Hospital).

${ }^{140}$ Preliminary Investigation of Probation Officer Anna Doyle (Feb. 7, 1923) (on file with Bedford Hills Files, Inmate No. 3374) [hereinafter Preliminary Investigation of Probation Officer, Inmate No. 3374].

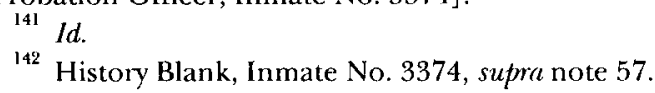


vation Army Home. ${ }^{143}$ When her father remarried, he allowed her to come home, but one year later Smith was sent back to the Salvation Army Home. ${ }^{144}$

This case also highlights how parental conflicts arose as a result of family members' gendered expectations that young women would automatically attend and contribute to household and familial responsibilities through physical work or, as in Smith's case, through wages. An examination of Smith's case illustrates how reformers attempted to use the law to address parental inadequacies. ${ }^{145}$ In one incident, Smith had been doing very well at the Salvation Army Home when her father disrupted her progress by demanding that she give him her wages. ${ }^{146} \mathrm{He}$ also threatened, unsuccessfully, to take Smith and the Home to court if they refused his request. ${ }^{147}$ Smith was later asked to leave the Home when she refused to abide by the rules. ${ }^{148}$ Upon her father's fifth complaint, lodged when she returned home after running away for a month, Smith was sent to Bedford. ${ }^{149}$

Smith's case shows a history of institutionalization and parental conflict, but as articulated by her probation officer, limited options for delinquent black women still played a central role in her Bedford commitment. "[T]he girl has been under supervision since she was ten years of age and all who have worked with her and tried to help her have failed. As she is colored there is only one institution where she can be sent and that is Bedford." ${ }^{150}$ While this officer may have believed that, despite Smith's extensive record, she still should have had options other than Bedford, Smith's race precluded this and Bedford was chosen not because it was the best choice but because it was the only choice.

In cases where black women were given probation, disgruntled relatives sometimes rejected the court's decision and requested insti-

\footnotetext{
${ }^{143}$ Preliminary Investigation of Probation Officer, Inmate No. 3374, supra note 140 .

144 Id.

145 See TAPPAN, supra note 19, at 95 ("[T]he [wayward minor act] is a 'parent's statute' which by its terms is designed to support or replace parental control.").

${ }^{146}$ Preliminary Investigation of Probation Officer, Inmate No. 3374, supra note 140 .

${ }_{148}^{147}$ Id.
} 
tutionalization." "[F] earing that [her seventeen-year-old niece] would come to harm through her bad associates," Daisy Mason's aunt and legal guardian filed a complaint and had Mason arrested as a wayward minor. ${ }^{152}$ Mason pled guilty, and the court offered probation; however, her aunt "absolutely refused" to take her home, and as a result she was committed to Bedford. ${ }^{159}$

Raised in a financially stable, two-parent home, ${ }^{154}$ Mason's problematic behavior stemmed from her rebellion against a strict upbringing. Mason refused to continue her education because she claimed that she wanted to work. ${ }^{155}$ Yet, she was never consistently employed and complained about her working conditions. ${ }^{156}$ She left one factory job and a position at a five-and-dime store because she claimed that it was "too hard standing on [her] feet all day." She was, as her file indicates, dedicated to staying out very late at night without permission, visiting friends, and going to dances and parties. ${ }^{158}$ Her aunt initially contacted the Church Mission of Help, a social service agency that worked with the State of New York, for aid and advice in handling Mason's constant lies about her activities and to express her fear that Mason was "drifting into bad company." 159 But all her aunt's "efforts to guide [and] discipline [Mason] ... failed." ${ }^{160}$ Mason's probation officer concluded that Mason's aunt was "a very kindly, conscientious superior old negress-probably ... [a] servant in a very fine family in the South." ${ }^{161}$ The officer, who was ordinarily quick to note the defi-

151 See ODEM, supra note 12, at 179 ("A few parents called for more drastic measures than a stern lecture or a short-term detention in Juvenile Hall. They wanted the court to place their daughters in a reformatory for a longer period of confinement.").

${ }^{152}$ Summary Report on Application for Parole (Jan. 7, 1930) (on file with Bedford Hills Files, Inmate No. 4107).

${ }^{153}$ Church Mission of Help Summary, Inmate No. 4107, supra note 58.

${ }^{154}$ See id. (noting that Mason's foster father earned one hundred dollars a month at the Greenwich Savings Bank and her foster mother, Mason's aunt, was a "superior colored woman").

155 Id.

${ }^{156}$ History Blank (June 5, 1926) (on file with Bedford Hills Files, Inmate No. 4107).

${ }^{157}$ Id

${ }^{158}$ Preliminary Investigation of Probation Officer A.C. Susth (n.d.) (on file with Bedford Hills Files, Inmate No. 4107) [hereinafter Preliminary Investigation of Probation Officer, Inmate No. 4107].

${ }^{159}$ Church Mission of Help Summary, Inmate No. 4107, supra note 58. 158.

${ }^{160}$ Preliminary Investigation of Probation Officer, Inmate No. 4107, supra note

${ }^{161}$ Id. The inmate's file suggests, however, that Mason's aunt was a native of New Jersey. $I d$. 
ciencies in working-class parents' notions of childrearing, liked Mason's aunt, who "impressed" her. ${ }^{162}$ The fact that Mason's aunt unhesitatingly relinquished her own attempts to guide Mason's moral behavior and welcomed the State's intervention helped her aunt to procure her desired result-commitment of her niece to an institution. Most importantly, this case illustrates how working-class black families and communities became socialized through their interactions with state representatives or state-sanctioned representatives, such as the Church Mission of Help, to accept certain ideas not simply about disruptive behavior within familial environments, but about what constituted illegal behavior and female criminality.

The Bedford cases not only reveal the conflicts between young women and family members over employment and social life, but they also illuminate these families' perspectives on out-of-wedlock pregnancies. Just as with other types of disobedience, family members of young single mothers believed that they needed to control their women's behavior. In fact, they were just as concerned about the danger of their kin "becoming morally depraved" after finding out about the pregnancy. For instance, one relative had her younger sister arrested and committed because she "habitually associated with dissolute persons," and as a result "became pregnant with child although unmarried." 163

While scholars agree that black parents and kin cared for, rather than ostracized, the children of single mothers, ${ }^{164}$ they have not emphasized the direct and personal effects of unwed pregnancies on working-class black families. An analysis of the case files of women sent to court and later to Bedford because of unwed pregnancies suggests the need to rethink the general argument that black families and communities were more likely than white families and communities to accept unwed pregnancies (and what is thought of as concomitant black female promiscuity). The case files provide a means for challenging scholars' arguments that black families failed to attach special stigma to inappropriate female behavior and illegitimate births. ${ }^{165}$

162 Id.

168 Commitment Papers (July 24, 1924) (on file with Bedford Hills Files, Inmate No. 3711$)$.

${ }_{164}$ See, e.g., PAula Giddings, When and WhERE I ENTER: THE IMPACT OF Black WOMEN ON RACE AND SEX IN AMERICA 152 (1984) (noting that the relatives of single black mothers in 1920s Harlem "would take the child [born out-of-wedlock] as their own").

See, e.g., ODEM, supra note 12, at 46 ("African Americans generally did not ostracize unmarried mothers [in the early twentieth century], but instead accepted and 
These cases show that families were not as nurturing or as accepting as generalities about "the black family" would hold. Such pregnancies created moral and financial tensions that affected the lives of both the young mothers and the families members who cared for them. Thus, although black families usually dealt with and accepted the children of single mothers, these same families did not therefore condone the behavior (or lifestyles) that led to the unwed pregnancies. As case files demonstrate, out-of-wedlock pregnancies, like other forms of legally questioned behavior, became a point of contention between single black mothers and their relatives.

Case files of women committed for out-of-wedlock pregnancies demonstrate the ways in which families struggled to survive with the additional financial burdens created by the sexual behavior of their young female members. Janet Green's mother requested the State's intervention because she could not adequately support her daughter's successive out-of-wedlock pregnancies. ${ }^{166}$ Green's mother brought her to the Women's Court because "she was mad" that, at seventeen,

cared for them and their children as members of the community."); $c f$. D'EMILIO \& FREEDMAN, supra note 59, at 97 ("[S]laves did not condemn premarital intercourse, and many adolescent girls had sexual relations. No special stigma attached to the young woman who bore an 'outside' child, that is, one born outside of marriage."); GUTMAN, supra note 11, at 63-75 (discussing the acceptance of premarital sex and unmarried pregnancies in slave communities). When addressing the behavior of a young lower-class single mother in Chicago in the late 1920s and early 1930s, Drake and Cayton argue:

Her friends may perhaps gossip about her, and her parents, if religious, will grieve over their daughter's sin; but she will hardly lose her friends, male or female, and will probably continue her activities in any organizations to which she belongs. The lower class, unlike the middle and the upper, not only tolerates illegitimacy, but actually seems almost indifferent toward it.

2 St. Clair Drake \& Horace R. Cayton, Black Metropolis: a Study of Negro LIFE IN A NORTHERN CTTY 590 (Harper \& Row, rev. \& enlarged ed. 1962) (1945). In short, say Drake and Cayton, the woman was not "disgraced." Id. For a lucid contextualization of the "cultural acceptance" theory, see Regina G. Kunzel, White Neurosis, Black Pathology: Constructing Out-of-Wedlock Pregnancy in the Wartime and Postwar United States, in NOT June CleAver: WOMEN AND GeNDER IN POSTWAR AMERICA, 1945-1960, at 304 (Joanne Meyerowitz ed., 1994).

See Author's Notes, Letter from Amy M. Prevost, New York State Reformatory Worker, Church Mission of Help, to Amos T. Baker, Superintendent, Bedford (Oct. 3, 1925) (original on file with Bedford Hills Files, Inmate No. 3367) [hereinafter Letter from Reformatory Worker to Bedford Superintendent, Inmate No. 3367] (indicating that Green's mother was already paying a woman to care for her daughter's oldest child and that Green's mother "[did] not feel she [could] assume any further financial responsibility"). 
Green was pregnant with her second child. ${ }^{167}$ After her arrest, Green was diagnosed and treated at a local hospital, but her mother refused to take her home and requested that she be committed to an institution. ${ }^{168}$ Her mother cared for her first child while Green had the second child in Bedford. ${ }^{169}$ After being released on parole, Green was sent back to Bedford because she violated parole by marrying "without permission" from Bedford administrators. ${ }^{170}$ When administrators discovered that Green was pregnant with her third child, they asked her mother to care for her second child, but she refused and asked that the child stay at Bedford. ${ }^{171}$ She explained that she was "already paying [six dollars] per week to the woman who care[d] for [Green's oldest] child during the day and that she $d$ [id] not feel she c[ould] assume any further financial responsibility." She was also "at a loss to know what [was] to become of [Green] and her babies [after her discharge] and asked... whether some arrangement could not be made whereby [Green] would remain in [Bedford] for another year." ${ }^{173}$ Realizing her inability to care for two children on her own, Green's mother took advantage of Bedford's legal responsibility to care for her daughter, which included supporting those children who were living with Green in Bedford. Green, however, disagreed with her mother's assessment. Green revealed that she had "no sense of guilt" regarding her behavior, refused to go back to her mother's home (possibly believing that she would be allowed to live with her husband), and subsequently requested parole work as a live-in domestic. $^{174}$

Family-initiated charges often reflected instances when a young woman's behavior or out-of-wedlock pregnancy threatened the moral and financial stability of the home. For example, Annie Dillard, an eighteen-year-old native of the British West Indies who was living with her sister and brother-in-law after her parents' deaths, was arrested as

${ }^{167}$ History Blank (Feb. 6, 1923) (on file with Bedford Hills Files, Inmate No. 3367) [hereinafter History Blank, Inmate No. 3367].

${ }^{168}$ Id.

${ }^{169}$ Letter from Reformatory Worker to Bedford Superintendent, Inmate No. 3367, supra note 166.

${ }^{170}$ Recommendation for Parole (Apr. 12, 1927) (on file with Bedford Hills Files, Inmate No. 3367).

${ }^{171}$ Letter from Reformatory Worker to Bedford Superintendent, Inmate No. 3367, supra note 166 .

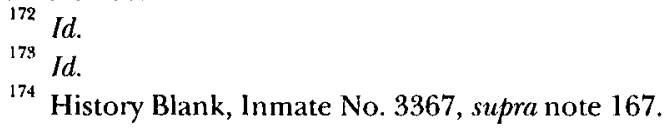


a result of the problems her pregnancy caused. ${ }^{175}$ Although she had been raised in a "religious atmosphere," belonging to the Pentecostal Reformed Church, ${ }^{176}$ after becoming pregnant Dillard was seen as promiscuous and without regard for her sister's trust. ${ }^{177}$ Because her sister's work schedule as a domestic meant that she was only at home in the evenings and on Sunday, ${ }^{178}$ Dillard was often unsupervised inside the home, with ample opportunity to meet with her boyfriend alone. Her sister, extremely disappointed by the resulting out-ofwedlock pregnancy, later revealed that Dillard's "difficulties were the result of over indulgence." 79 She acknowledged that Dillard was the youngest of four children, and "it seem[ed] that her brothers and sisters ... all united in spoiling her."

Dillard's pregnancy threatened a relatively stable working-class home by creating additional financial and familial responsibilities. Her sister and brother-in-law worked incessantly to provide for Dillard and their own four children, whose ages ranged from six months to seven years. ${ }^{181}$ In addition to these burdens, Dillard's pregnancy also served as a constant reminder of her outright disobedience and, according to her family's religious beliefs, her moral sin. In her family's estimation, only marriage could redeem her. When Dillard's boyfriend reneged on his promise of marriage, her sister filed a complaint and had Dillard committed to Bedford. ${ }^{182}$ It is not clear whether Dillard's family filed further charges against her boyfriend, but, in any case, he would not have been charged as a wayward minor because this law did not apply to young men until a year after Dillard's 1924 Bedford commitment. ${ }^{189}$ Dillard, however, could not "say

${ }^{175}$ History Blank, Inmate No. 3711, supra note 68.

${ }^{176}$ Higginbotham argues that "[ $\mathrm{t}$ ]he storefront Baptist, Pentecostal, and Holiness churches along with a variety of urban sects and cults ... were doubtless more effective than middle-class reformers in policing the black woman's body and demanding conformity to strict guidelines of gender roles and sexual conduct." Evelyn Brooks Higginbotham, Rethinking Vernacular Culture: Black Religion and Race Records in the 1920s and 1930s, in THE HOUSE THAT RACE BUILT 157, 171 (Wahneema Lubiano ed., 1997).

${ }^{177}$ Letter from Amy M. Prevost, New York State Reformatory Worker, Church Mission of Help, to Amos T. Baker, Superintendent, Bedford (Jan. 9, 1925) (on file with Bedford Hills Files, Inmate No. 3711).

${ }^{178}$ Id.

179 Id.

$180 \mathrm{Id}$.

181 History Blank, Inmate No. 3711, supra note 68.

182 Id.

${ }^{183}$ See Act of Apr. 8, 1925, ch. 389, secs. 1-2, $\$ \$ 913$-a to -d, 1925 N.Y. Laws 711, 711-12 (subjecting young boys to the law by substituting the word "person" for "fe- 
whether or not [Bedford was] the place for her," ${ }^{, 184}$ and, after her parole, she continued to experience problems with family members, who never failed to remind her of her major moral shortcomings. ${ }^{185}$

Family members also used the wayward minor laws when their relatives' behavior was seen as a negative influence within their community. Ellie Davis's promiscuity and pregnancies not only affected her family's reputation but were seen as troubling examples for other young black women in her small upstate New York town. ${ }^{186}$ Twentyyear-old Davis had two children by the time of her Bedford commitment. ${ }^{187}$ Her first child was illegitimate, but she married the father of her second child. ${ }^{188}$ Soon after their marriage, Davis's husband was arrested and imprisoned on grand larceny charges. ${ }^{189}$ When her mother died a year later, Davis's father said that she "could come home with her two children and keep house for him [and a younger sister and brother]. ${ }^{" 90}$ Her father, a long-time employee of an electric company, also promised that he would "provide for her if she kept straight." ${ }^{\prime 19}$ This arrangement did not last for long. Six months later, Davis's father went "to the Police Magistrate, signed the complaint, and asked to have [her] sent away" because she "had been running out nights with different men" and was expecting her third child; he therefore felt that she had to be removed from his home. ${ }^{192}$ Reminiscent of the gendered expectations of Mabel Smith's case, ${ }^{199}$ Davis's recently widowed father's concern about her behavior coincided with

male"); cf. Mary E. Odem \& Steven Schlossman, Guardians of Virtue: The Juvenile Court and Female Delinquency in Early 20th-Century Los Angeles, 37 CRIME \& DELINQ. 186, 194 (1991) (concluding that "boys were far less likely than girls to have their lives scrutinized or disrupted for status and moral offenses").

${ }^{184}$ History Blank, Inmate No. 3711, supra note 68.

${ }^{185}$ See Author's Notes, Letter from Amy M. Prevost, New York State Reformatory Worker, Church Mission of Help, to Amos T. Baker, Superintendent, Bedford (Jan. 28, 1926) (original on file with Bedford Hills Files, Inmate No. 3711) (indicating that Dillard's sister was "inclined to remind [Dillard] of the fact that she [was] an unmarried" mother and also "to complain of the extra work which [her] baby ma[de] in the house").

${ }^{186}$ History Blank, Inmate No. 4059, supra note 55.

${ }^{187} \mathrm{Id}$.

${ }^{188}$ Recommendation for Parole (Dec. 7, 1926) (on file with Bedford Hills Files, Inmate No. 4059) [hereinafter Recommendation for Parole, Inmate No. 4059].

189 Id.

190 Letter from Agent to Reformatory Worker, Inmate No. 4059, supra note 55, at 1 .

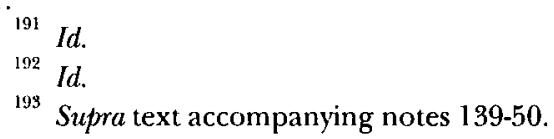


his practical need for someone to run his household and take care of his children. Davis's pregnancy thus created a moral and domestic dilemma: she was having an out-of-wedlock child, and that pregnancy would undoubtedly interfere with how her father's household would be managed.

Although Davis was committed to Bedford by her father, the local agent for the State Charities Aid Association agreed that she should be imprisoned, since her sexually promiscuous behavior in the black community was "extremely dangerous for the rest of the girls and for her younger sister." ${ }^{194}$ Davis's father and the community also deemed her behavior unacceptable not only because of what they believed was her uncontrollable promiscuity, but also, and more importantly, because her behavior set an undesirable example for her younger sister. $^{195}$ Her actions in a small black community were also more carefully scrutinized than they would have been in a larger urban environment. Moreover, although her father held a good job, ${ }^{196}$ supporting his family as well as Davis's children posed significant financial burdens. In the end, social workers and her father argued that Davis needed to be sent to Bedford for the benefit of the community rather than for her rehabilitation. ${ }^{197}$ Indeed, they believed the young women in their community were "in danger of becoming morally depraved" because of Davis's behavior, which they feared jeopardized the stability of the entire community. ${ }^{198}$ Davis later revealed that her Bedford commitment was "[m]aybe a good thing," as she had to learn the "lesson to leave men alone." 199

These kinds of cases illustrate the varied responses of black working-class families to general and particular types of disobedience. Clearly unaware of the dire circumstances related to black women's access to rehabilitative services, black family members used the wayward minor laws to address their individual concerns. A number of relatives dismissed probation, insisting that their young women

\footnotetext{
${ }^{194}$ Letter from Agent to Reformatory Worker, Inmate No. 4059, supra note 55, at 1.

195 See Recommendation for Parole, Inmate No. 4059, supra note 188 (indicating that Davis's father committed her because of his "[f] eeling that she was a menace to the younger sister still at home and to other girls in the neighborhood").

${ }^{196}$ See id. (noting that Davis's father's job at an electric company gave him "plenty of income").

${ }^{197}$ Letter from Agent to Reformatory Worker, Inmate No. 4059, supra note 55, at $1-2$.

198 Id.

199 History Blank, Inmate No. 4059, supra note 55.
} 
needed institutional discipline and rehabilitation. ${ }^{200}$ These family members' concerns about their young women indicate an implicit strategy of resistance to the urban vices they knew their young women faced, as well as to the negative stereotypes of black female sexuality. Disciplining young women therefore meant controlling their sexuality not only as a preventive measure but also, and just as importantly, as a reaction to them becoming single mothers. Thus, out-of-wedlock pregnancies underscore these families' general and ongoing concerns about appropriate black female behavior and, specifically, black female sexuality. Moreover, family members' responses to out-ofwedlock pregnancies challenge the notion that these families were more likely to accept single mothers and their children without attention to their own established notions of morality and respectability. As members of black working-class communities, they faced the everyday difficulties of surviving in nuclear and extended families. When faced with the unexpected pregnancies of their female kin, these black family members forcefully rejected the moral and financial burdens that would inevitably come with single parenthood; when dealing with other forms of legally defined aberrant behavior, they used the services of the State and hoped that confinement in Bedford would serve as an alternative means of parental discipline.

\section{Did The LaW REALly Help Black WORKING-Class PaRENTS?}

Commitments to Bedford elicited a range of responses from black families. Relatives often sought a young woman's release from Bedford when they believed she had learned her lesson, ${ }^{201}$ but families and the State rarely agreed on the degree of rehabilitation necessary. ${ }^{202}$ In many instances, relatives believed that an arrest or the scare

${ }^{200}$ Daisy Mason, for example, was offered probation, but her aunt refused to take her home, insisting upon her commitment at Bedford. Church Mission of Help Summary, Inmate No. 4107, supra note 58.

${ }^{201}$ See, e.g., Letter from Amy M. Prevost, New York State Reformatory Worker, Church Mission of Help, to Amos T. Baker, Superintendent, Bedford 1 (Sept. 26, 1925) (on file with Bedford Hills Files, Inmate No. 3711) [hereinafter Letter from Reformatory Worker to Superintendent, Inmate No. 3711] (indicating that Dillard's sister was "quite willing to have with her, provided she distinctly underst[ood] that she must conduct herself properly and keep off the streets at night").

${ }^{202}$ See, e.g., Author's Notes, Letter from Inmate's Mother to Superintendent, Bedford (Mar. 21, 1927) (original on file with Bedford Hills Files, Inmate No. 3367) [hereinafter Letter from Inmate's Mother to Superintendent, Inmate No. 3367) ("Please see [to my daughter's discharge] as soon as possible... or let me know why they are keep[ing] her [in Bedford] so long.... [S] he [h] as spen[t] almost 4 year[s] in the $[\mathrm{re}] . . .$. ). 
of bringing a young woman into court would be enough punishment to change their female kin's inappropriate behavior. ${ }^{203}$ They would then seek to halt the criminal justice process but were often met with the sentiment that one administrator expressed: "I don't see how they can control her any better now than before." bers, however, disagreed with what they saw as a rather liberal parole policy. One father wrote Bedford officials after his daughter had come up for parole after spending seven months there:

[I] t was not my intention to have [her] released to[o] shortly. But as much as your Board of Managers has seen fit to grant her a Parole and on the conditions as stated in your letter I will gladly receive her. I beg to [thank] you and [Bedford] for having aided me ... ${ }^{205}$

However, cases such as this were rare in the sample studied.

Families' loss of authority over their female relatives to the State became clear when they sought to reverse or end their Bedford commitment. Many families needed their female kin back at home to help with domestic responsibilities and other needs. ${ }^{206}$ Second thoughts about their relatives' commitment often arose when families encountered hard times due to the loss of a wage earner. ${ }^{207}$ Miranda Edmonds, a seventeen-year-old native of North Carolina, ${ }^{208}$ was committed to Bedford after her first act of disobedience. ${ }^{209}$ After migrating to New York with her mother and two younger sisters (her father remained in the South), ${ }^{210}$ Edmonds received private tutoring until the eighth grade but decided to go to work because all of her female

${ }^{203}$ See, e.g., Staff Meeting, Inmate No. 2486, supra note 71 ("[The inmate's parents felt] the scare of bringing her into court would [have been] enough punishment[, asking, 'It] was really not a legal commitment, was it? [']").

${ }_{205}^{204}$ Id.

${ }^{205}$ Letter from Inmate's Father to Amos T. Baker, Superintendent, Bedford (Mar. 17, 1924) (on file with Bedford Hills Files, Inmate No. 3476).

${ }^{206}$ See, e.g., Letter from Agent to Reformatory Worker, Inmate No. 4059, supra note 55 , at 1 (indicating that the inmate's father would allow her to come home from Bedford if she "ke[pt] house for him" and the inmate's younger sister and brother).

${ }^{207}$ See, e.g., Preliminary Investigation of Probation Officer, Inmate No. 3374, supra note 140 (displaying the severity of one family's financial position, as the "[f]ather threatened to take [his daughter] . . to court if her wages were not given to him").

${ }^{208}$ Admission Record (Feb. 5, 1926) (on file with Bedford Hills Files, Inmate No. 4028) [hereinafter Admission Record, Inmate No. 4028].

${ }^{209}$ History Blank (Feb. 16, 1926) (on file with Bedford Hills Files, Inmate No. 4028).

${ }^{210}$ It is unclear from the case file whether Edmonds's father remained in North Carolina or moved elsewhere in the South. See id. ("Father stays south, but mother comes north."). 
friends worked. ${ }^{211}$ Employed in general housework and in a candy factory, Edmonds's troubles began after she spent three nights with her boyfriend. ${ }^{212}$ When she returned home, her mother had her arrested. $^{219}$ According to Edmonds, the court gave her six months' probation but her mother said, "Send her away." 214 Consequently, Edmonds was committed to Bedford as a wayward minor in February $1926 .{ }^{215}$ By June 1926, Edmonds's mother needed her back at home and wrote Bedford pleading for her release. ${ }^{216}$

During Edmonds's imprisonment, her mother's health and financial position deteriorated as a result of her becoming the guardian for two orphaned nieces and nephews, recently arrived from the South. ${ }^{217}$ Edmonds's mother's poor health affected the entire family, as "her doctor advised her to give up doing laundry work," which had been her primary source of financial support "for years." mother could not follow her doctor's advice without Edmonds's release from Bedford. ${ }^{219}$ "I imagine you have my picture," she wrote Superintendent Amos Baker, "and can reali[z]e what it is to be [a] father and mother for three children." "Please let her come and help me [so] I can rest a little . ..." "I "I am feeling very bad both physical[ly] and mental[ly]," she explained. ${ }^{222}$ "[M]y physical trouble is [that] I am al[most] bro[ken] down from hard work and need help very bad....,228 Yet Bedford denied her repeated and increasingly desperate requests for her daughter's release.

211 Id.

212 See id. (indicating that Edmonds was arrested after spending three consecutive nights with her boyfriend going to shows, seeing movies, and getting ice cream).

213 Id.

214 Id

215 Admission Record, Inmate No. 4028, supra note 208.

216 Author's Notes, Letter from Inmate's Mother to Amos T. Baker, Superintendent, Bedford (June 20, 1926) (original on file with Bedford Hills Files, Inmate No. 4028) [hereinafter Letter from Inmate's Mother to Superintendent, Inmate No. 4028].

${ }^{217}$ Author's Notes, Letter from Elizabeth Kjaer, Social Worker, City Mission Society, to Amos T. Baker, Superintendent, Bedford (Oct. 7, 1926) (original on file with Bedford Hills Files, Inmate No. 4028).

218 Id.

${ }^{219}$ ld.

${ }^{220}$ Letter from Inmate's Mother to Superintendent, Inmate No. 4028, supra note 216.

$$
\begin{array}{ll}
{ }_{222}^{221} & I d . \\
{ }_{223} & I d . \\
{ }_{22} & I d .
\end{array}
$$


Edmonds's mother's letter, like so many others, explained that she had done what she thought she was supposed to do and that she now believed her daughter had learned her lesson:

I fe[e]l she has be[e]n punish[ed] enough[. T] he co[u]rt told me she would be sent there [for] three months and then be return[ed] back to me on probation[. I]f she did not prove good[,] they would take her back for the remain[der] of the three years[. I]t was hard but for her disob[e]ying me and staying out... with bad company [but] I th[ink probation is] best for her.

Seventeen-year-old Harriet Parker was committed to Bedford for disobeying her parents' rules, staying out all night, and refusing to return home. ${ }^{225}$ Less than a year into her sentence, Parker's mother requested that she be paroled; ${ }^{226}$ however, her request was denied. ${ }^{227}$ Six months later, she again requested Parker's release, explaining:

[I am] begging you to let me have my child [so] she may help to brighten my days on this earth .... I am now confined to my bed .... I ha[v]e a good comfortable home but I need [to have someone] with me as [my husband] has to go to work and my daughter and son-in-law ... are gone all day. Oh I hope and pray that you will grant me my child and $[\mathrm{G}]$ od will ever bless you. ${ }^{228}$

Disregarding her plea for Parker's release, Bedford again denied her request, explaining that Parker's best interests would be served if she stayed at Bedford:

[Your daughter] has been with us only a little over a year, and while I realize that you probably need her help at home, I feel that [she] should have [the] opportunity for further training in [Bedford] before being tried on parole. I am glad to report that she is doing very well and has a good record with us. ${ }^{229}$

$224 I d$.

${ }^{225}$ Author's Notes, Verified History (n.d.) (original on file with Bedford Hills Files, Inmate No. 2682).

${ }^{226}$ Author's Notes, Letter from Inmate's Mother to Helen Cobb, Superintendent, Bedford (July 20, 1919) (original on file with Bedford Hills Files, Inmate No. 2682).

${ }^{227}$ See Author's Notes, Letter from Helen Cobb, Superintendent, Bedford, to Inmate's Mother (July 24, 1919) (original on file with Bedford Hills Files, Inmate No. 2682) ("As you know, [your daughter] has not yet been with us a year, and while she is doing nicely [at Bedford], I am quite sure the Managers would not feel justified in considering her for parol[e] at this time.").

${ }^{228}$ Author's Notes, Letter from Inmate's Mother to Helen Cobb, Superintendent, Bedford (Jan. 18, 1920) (original on file with Bedford Hills Files, Inmate No. 2682).

${ }^{229}$ Author's Notes, Letter from Helen Cobb, Superintendent, Bedford, to Inmate's Mother (Jan. 19, 1920) (original on file with Bedford Hills Files, Inmate No. 2682). Despite her mother writing yet another letter on March 20, 1920, requesting 
In another case, the mother of a young woman who violated parole and who had been imprisoned under several superintendents' administrations believed that, after four years, her daughter should have been released: "I am asking you why are you all keep[ing] ... my daughter so long .... [S] [Se could be out to work for her children as I am gett[ing] almost under [caring for them. My daughter] was not put [in Bedford] for any thing that was bad." ${ }^{230}$ Once again, the State's intervention often placed the State's perception of a young female's needs over her family's immediate and stated need for the woman's presence in the home. ${ }^{231}$ These particular cases reveal the unequal power relations not only between the State and the working class but also between young women and their families. While there were particular expectations regarding young women's behavior outside of the home, these families also had specific, gendered expectations regarding how and why these women should be returned to their homes to address their domestic, and presumably natural, responsibilities.

Other case files reveal that sometimes family members simply believed their kin had served enough time. Two years into seventeenyear-old Lynette Moore's sentence, her mother went to Bedford in order to secure her release. ${ }^{232}$ The Superintendent denied her mother's request because of Moore's improper actions in Bedford. ${ }^{233}$ After Moore's mother sought legal counsel, the Superintendent noted that Moore "was not able to make good when she was with [her parents] before and [that she] very much doubt[ed Moore's] ability to do so now." ${ }^{294}$ As a result, her parents found that even though they had consented to their daughter's imprisonment for training and rehabili-

her daughter's release (which was denied by Superintendent Cobb on March 24, 1920), Parker was not released until July 20, 1920. Recommendation for Parole (n.d.) (on file with Bedford Hills Files, Inmate No. 2682).

${ }^{230}$ Letter from Inmate's Mother to Superintendent, Inmate No. 3367, supra note 202.

${ }^{231}$ See ALEXANDER, supra note 12, at 106 ("[R] eformatory officials and staff... lacked confidence in family members' ability to serve as reliable advocates of behavioral reform. Simply put, they doubted the 'good sense' of the inmates' 'real' families and fully expected kin to obstruct as often as facilitate reform."); ODEM, supra note 12, at 188 ("Parents could initiate cases, but they could not necessarily count on court decisions to fit their needs, for they were not equal partners in the negotiation process.").

2:2 Author's Notes, Letter from Helen Cobb, Superintendent, Bedford, to J.A. Armstrong, Justice of the Peace (June 14, 1919) (original on file with Bedford Hills Files, Inmate No. 2503).

${ }_{234}^{234} \begin{aligned} & \text { Id } \\ & \text { Id. }\end{aligned}$ 
tation initially, once the State intervened they, in fact, jeopardized their parental rights.

Most working-class black family members experienced mixed feelings about the ultimate impact of the wayward minor laws on their female relatives' behavior. Imprisonment and, in some cases, probation presented alternative disciplinary options for relatives concerned with their young women's rebellious and disrespectful behavior. By placing their female kin in institutions that focused on rehabilitation, most relatives felt rather assured that these young women would benefit from a more regimented and focused disciplinary environment. Yet these same families failed to realize that, while the law addressed some of their anxieties, invoking the law also served as an assertion of parental and guardian incompetence in the eyes of the State. The State's ambivalence toward working-class families' capacities for parenting can be seen in administrators' responses to these relatives' attempts to modify or end their female kin's institutional commitments. In focusing primarily on how they could reform young women, State administrators failed to think seriously about the needs of the families that these women would rejoin.

\section{CONCLUSION}

In presenting the problems of single black women through the perspective of working-class families, we can begin to reconsider the myriad ways in which black communities navigated, negotiated, and responded to New York's urban terrain. Exploring, through the wayward minor laws, the anxieties prevalent in black working-class families about black women's moral behavior expands our understanding and conception of urban reform, criminal justice initiatives, and race. While the law applied to all young women in New York State beginning in 1886, the implications for, and consequences of, its use in black communities reveal how diverse working-class black families handled the diverging and sometimes overlapping attempts to protect and regulate the behavior of black women in early-twentieth-century New York, as well as the impact of racism on black female offenders and their communities.

The Article shifts the historical discussion of black women's protection away from the efforts of elite black and white reformers and focuses on the concerns of black working-class families. Black family members' active involvement in the reform process illustrates how they implemented their moral principles through the law and the State. Cases of reported disobedience, including out-of-wedlock 
pregnancies, challenge the general assertions about working-class black communities' capacity and ability to enact moral stature, as well as the commonly noted argument that working-class communities had a "cultural acceptance" of unwed mothers and their children. ${ }^{295}$ For instance, at the end of one woman's commitment for becoming pregnant, her sister pushed for the baby to be paroled into her care. ${ }^{236}$ At the same time, however, she emphasized that she would only deal with her convicted sister if the latter "distinctly underst[ood] that she must conduct herself properly., ${ }^{, 237}$

Nevertheless, racism within the criminal justice system underlay the basic attempts of those relatives who used state intervention to stabilize family relationships, and, further, it reified stereotypes about black women's innate criminality. When denied services geared toward dealing with women who were defined as being "in danger of becoming morally depraved," black women were sentenced, usually as first offenders, to state institutions that served as the final resort in most white women's cases. In the end, there were some instances where the State addressed parental concerns successfully, but, in large part, the unequal power dynamics between the State and the working class resulted in parents and guardians losing their natural and legal authority over their female kin.

Conflicts within black communities were not simply the result of tensions between reformers and the black working-class masses but resulted from the fact that working-class family members had their own ideas and expectations about black women's respectability and moral${ }^{i t y}{ }^{238}$ that, in many instances, conflicted with what these women wanted for themselves. Even though the wayward minor laws provided family members with a means to protect these young women from very real urban vices, they also provided relatives with an opportunity to regulate young women's behavior over conflicts that ranged from personal disputes to automatic gendered assumptions that these

${ }^{295}$ See, e.g., Kunzel, supra note 165, at 316 ("Rather than provide an index of immorality, illegitimacy [in black communities] . . was better understood as an adaptation to environmental and social conditions.").

236 Letter from Reformatory Worker to Superintendent, Inmate No. 3711, supra note 201 , at 1 .

$297 \mathrm{Id}$.

${ }^{238}$ For more detailed discussions of these ideas and expectations, see Higginbotham, supra note 176; Tera W. Hunter, "The 'Brotherly Love' for Which This City Is Proverbial Should Extend to All": The Everyday Lives of Working-Class Women in Philadelphia and Atlanta in the 1890s, in W.E.B. DuBoIs, RACE, AND THE CrIY 127 (Michael B. Katz \& Thomas J. Sugrue eds., 1998). 
women should be responsible for household and domestic matters. Thus, the use of the laws and many of these women's subsequent imprisonments in state institutions, rather than their probation or incarceration in local rehabilitative institutions, caused many of these young women's attempts at independence (social, economic, and sexual) to be equated with black female criminality.

While wayward minor case files definitely reveal the power struggles within some working-class black families, they also illustrate relatives' deep concerns about their female kin's welfare. After her niece disappeared and subsequently violated her parole, one inmate's aunt wrote, "I am still worr[i]ed about her [as] I have not h[ea]rd one word." "She noted that, as an inmate at Bedford, she at least knew her niece was safe, but she revealed her overriding fear when addressing her niece's prolonged departure: "I don't know whether she is sick... or [whether] she is dead ...."240 Unlike reformers, black families had a distinct and personal investment in the perceived or eventual downfall of black women. To black relatives, these women were more than professional case studies or representatives of the race; they were their daughters, sisters, nieces, and granddaughters, whose actions affected their entire families' well-being.

${ }^{239}$ Letter from Jennie Lythcott, Inmate's Aunt, to Amy M. Prevost, New York State Reformatory Worker, Church Mission of Help 1 (Mar. 2, 1924) (on file with Bedford Hills Files, Inmate No. 3387).

${ }^{240} I d$. 
